\title{
Cantarias e pedreiras históricas do Rio de Janeiro: instrumentos potenciais de divulgação das Ciências Geológicas
}

\author{
Soraya Almeida \\ Depto. de Geociências, UFRuralRJ,Seropédica. \\ soraya@ufrrj.br \\ Rubem Porto Junior \\ Depto. de Geociências, UFRuralRJ,Seropédica. \\ rubempjr@gmail.com
}

\begin{abstract}
Historic quarries in Rio de Janeiro as a stimulus to the study of Geological Sciencies: The use of rocks as the main source of raw material for building construction was a peculiar characteristic of the Rio de Janeiro city and surroundings, since its founding until the nineteenth century. The historical quarries have influenced the urban layout and the formation of settlements, with connections in all economic strata. Nowadays, the extracted material is exposed at the historical part of the City, known as Rio Antigo (Old Rio) where is possible to see various examples of rock use. The paper summarizes the historical role played by the quarries in the city and proposes ways to use this heritage as a way of encouraging the dissemination of science, the study of geology and the recognition of the link between Man and rock.
\end{abstract}

KEYWORDS Quarry, Rio de Janeiro, History, Geology, urban development.

RESUMO A utilização de rochas como principal fonte de matéria-prima para construção de edifícios era característica peculiar à cidade do Rio de janeiro e arredores, desde sua fundação até o século XIX. As pedreiras históricas influenciaram o traçado urbano e a formação de núcleos populacionais, com conexões econômicas em todos os estratos sociais. $O$ material delas extraído hoje se encontra, em suas diversas formas de uso, expostos no conjunto arquitetônico do chamado Rio Antigo, situado no centro econômico e turístico da capital. O trabalho sintetiza o papel histórico desempenhado pelas pedreiras na cidade e propõe formas de uso deste patrimônio como estímulo à divulgação da ciência, ao estudo de geologia e ao reconhecimento do vínculo existente entre o Homem e a rocha.

PALAVRAS-CHAVES Pedreira, Rio de Janeiro, História, Geologia, desenvolvimento urbano.

\section{Introdução}

Estudos históricos permitem ao homem situar-se no espaço e no tempo, trazendo consigo o sentimento de continuidade e a percepção de que sua condição atual resulta de ações passadas e são determinantes de seu futuro. Assim como a história estuda o Homem e sua situação no tempo e espaço, a geologia também discute as relações de tempo-espaço, utilizando química, física e matemática como instrumentos de investigação, trabalhando com uma escala na qual o tempo da existência humana não passa de uma pequena fração. Contudo, se o estudo de história traz em si um compo- nente emocional (sentimento de continuidade da própria existência), ao estudo da geologia é atribuída uma perspectiva predominantemente racional.

A premissa de que a história insere-se exclusivamente na área dos estudos humanos e a geologia,nas ciências exatas não é, entretanto, verdadeira. Desde sempre, os historiadores fizeram uso de ferramentas matemáticas em seus estudos. Técnicas modernas de análise, como raios-X, tomografia e decodificação de DNA são cada vez mais utilizadas em investigações históricas, enquanto os avanços na área de ciências exatas sempre estiveram submetidos às transformações socioeconômicas, políticas e religiosas. Os exemplos são muitos: equipamentos 
atualmente utilizados em diversas áreas de pesquisa tiveram sua origem associada a projetos bélicos; questões religiosas ainda influenciam na aceitação de teses científicas, assim como interesses comerciais determinam o caminho a ser tomado por pesquisadores na definição de seus temas de trabalho. A evolução das ciências exatas está, portanto, diretamente ligada aos mais variados interesses humanos, e conhecer estas conexões contribui para tornar seu estudo mais atraente.

No Brasil, a falta de interesse em temas ligados a ciências exatas, comum entre jovens de todo o mundo, é intensificada pelas deficiências no ensino de física, química e matemática na rede escolar. No caso específico da geologia, a disparidade existente entre "tempo geológico" e "tempo humano" adiciona uma barreira à compreensão do elo existente entre o homem e o tema de estudo. A transposição desta barreira pode, todavia, ser facilitada se o interesse do público para questões relacionadas às rochas for estimulado pela divulgação da importância dos fenômenos geológicos e do uso de minérios no cotidiano da humanidade.

Rodeadas por maciços rochosos, as cidades que ocupam a região do Grande Rio compõem um ambiente propício a este tipo de percepção, pois desde sua origem, no Brasil colonial, o desenvolvimentos dessas cidades é condicionado pela indústria da extração de rochas. $\mathrm{Na}$ Cidade do Rio de Janeiro, em particular, construções históricas e gigantescos aterros atestam o papel fundamental das pedreiras na evolução da cidade. Expostas nas cantarias de edifícios históricos, as rochas são testemunhos da história do crescimento urbano e constituem registros petrográficos obtidos pelo avanço das frentes de lavra ao longo de séculos.

Contudo, apesar do incremento do número de publicações sobre a geologia do Rio de Janeiro nas décadas de 80 e 90 (Pires et al. 1983; Porto Jr. \& Valente 1988; Pires et al. 1989; Porto Jr. 1994; Porto Jr. 1996; Porto Jr. \& Aguiar 2000; Aguiar 2002; dentre outros), a literatura especializada é deficiente em informações sobre a exploração de pedreiras no período situado entre o início da colonização a meados do século XX, quando a atividade de extração passou a ser monitorada pelo Departamento Nacional de Produção Mineral (DNPM). Referências sobre estas explorações e seu impacto social são encontradas, apenas, em textos não especializados, na forma de descrições produzidas por viajantes estrangeiros em visita à região. Grande parte das fontes bibliográficas está, portanto, à margem da literatura geológica tradicional e contida em textos históricos onde as menções sobre a geologia local ou sobre a exploração das pedreiras constituem trechos de narrativas extensas que discorrem sobre vários aspectos da sociedade e da natureza local. A mesma carência de dados é observada em relação à localização das antigas pedreiras.

A carta geológico-geotécnica publicada pela Prefeitura Municipal do Rio de Janeiro (1997) assinala a localização de várias frentes de lavras abandonadas, mas não traz representada a totalidade destas antigas extrações. Desta forma, os dados sobre as posições destas frentes, no trabalho aqui apresentado, resultam de correlações entre dados fornecidos pela prefeitura, textos históricos e fontes iconográficas (mapas, pinturas e fotografias históricas).

As informações obtidas revelam que, tanto no núcleo urbano colonial, como nas áreas então rurais que hoje fazem parte do Grande Rio, as pedreiras tiveram um papel fundamental no desenvolvimento urbano. Cada uma destas regiões apresenta particularidades históricas relativas à exploração mineral que abrem várias possibilidades de desenvolvimento de pesquisa. No presente texto, o conjunto arquitetônico do Rio Antigo, no centro da cidade, foi selecionado como exemplo de "estudo de caso", devido à sua importância histórica e à facilidade de acesso ao local, o que permite a realização de atividades didáticas por meio do contato direto com os objetos de estudo, em visitas guiadas às pedreiras e edifícios históricos.

\section{Os litotipos explorados}

O mercado de explotação de brita e material de cantaria está, atualmente, em plena expansão. Entretanto, ele convive com demandas ambientais que vem provocando o contínuo deslocamento das pedreiras para a periferia da Cidade do Rio de Janeiro. Atualmente, os maiores empreendimentos estão localizados nos municípios limítrofes à cidade, como Japerí, Seropédica, Nova Iguaçu e Itaguaí. As rochas exploradas são, contudo, distintas daquelas que caracterizam a fase inicial de extração, no período colonial. Enquanto a exploração inicial foi caracterizada por tipos preferencialmente facoidais (gnaisse facoidal, kinzigitos semi-facoidais, por exemplo), atualmente a exploração se concentra 
em tipos texturais mais homogêneos (ortognaisses granodioríticos - preferencialmente - para brita e granitos para cantaria).

No intervalo que compreende o início da extração, até os dias atuais, uma grande variedade de rochas, como granitos, gnaisses, dioritos, gabros e rochas alcalinas foi explotada para uso em construção civil (Abreu 1957). Estes termos gerais compreendem um conjunto litológico integrante da Faixa Ribeira, com unidades geradas em diferentes etapas de sua evolução geológica, cujo quadro é sintetizado por Heilbron et al. (1994) com a proposta de uma evolução tectonometamórfica para o segmento central desta faixa pela ação de empurrões dúcteis e dobras relacionadas ao evento de deformação principal. Um modelo de colisão oblíqua baseado em dados estruturais obtidos em trabalhos de campo e testes experimentais é apontado pelos autores como vantajoso por se adequar, com perfeição, à evolução metamórfica da área, caracterizada por um estágio inicial de metamorfismo de pressão intermediária a alta, seguida por uma fase de pressão mais baixa. $\mathrm{O}$ forte encurtamento e espessamento crustal, que resultaria da deformação principal, explicaria a grande quantidade de granitoides dos tipos I e S progressivamente mais abundantes em direção ao segmento interno da Faixa. Heilbron et al. (1995) definem quatro domínios tectônicos na região, como resultado da evolução do segmento durante a Orogênese Brasiliana: 1) embasamento pré $1,8 \mathrm{Ga}$ (rochas formadas e/ou retrabalhadas no Evento Transamazônico); 2) ortognaisses indivisos sem dados geocronológicos e assumidos como integrantes do embasamento; 3 ) cobertura metassedimentar Pós- 1,8 Ga; e 4) rochas granitoides. Com base nos dados geocronólogicos a Orogênese Brasiliana foi subdividida em três períodos: Sin-colisional (590-563 Ma); Pós-colisional (535-520 Ma) e Pós-tectônico (503-492 Ma). Tupinambá et al. (1998) definem para o Terreno Oriental, onde se insere geograficamente o município do Rio de Janeiro, as seguintes associações litológicas: a) ortognaisses tonalíticos a granodioríticos, gnaisses leucograníticos, corpos quartzo dioríticos, que compõe o Complexo Rio Negro; b) ortognaisse granodiorítico a granítico (Batólito Serra dos Órgãos) intrusivo no Complexo Rio Negro; c) rochas metassedimentares de alto grau correspondentes a rochas do Grupo Paraíba do Sul; e d) corpos (stocks e sills) de rochas graníticas não foliadas. A evolução tectonomagmática para o orógeno
Brasiliano nos limites do Terreno Oriental inclui, segundo Tupinambá (1999), um magmatismo pré-colisional representado por tonalitos e diorito gnaisses componentes do Complexo Rio Negro e por corpos de hornblenda gabros, evoluídos em uma série cálcica gerada em ambiente de arco de ilhas oceânico ativo entre 630-600 Ma (Arco Rio Negro). Esse arco, em uma etapa posterior, colidiu com uma margem passiva, (Terreno Oriental da Faixa Ribeira), gerando espessamento crustal, ampla migmatização e geração de magmas graníticos do tipo S. O autor propõe que, após a colisão e a acresção do arco à margem passiva, um novo arco magmático, agora de características continentais, se estabeleceu a $560 \mathrm{Ma}$, sendo o Batólito Serra dos Órgãos representante deste magmatismo associado a um processo de subducção com mergulho inverso ao apresentado pelo Arco Rio Negro. O rápido soerguimento do Batólito Serra dos Órgãos gerou um sistema de falha normais transversais ao orógeno, tendo essas estruturas controlado o transporte e a colocação dos magmas graníticos pós-colisionais.

Deste conjunto de rochas, o gnaisse facoidal é o que mais se destaca como pedra de cantaria, ornando fachadas de antigas moradias e diversos monumentos históricos da cidade do Rio de Janeiro. Do grego phakoeidés (lentícula), também conhecido como "augen-gnaisse" - do alemão Augen (olhos) - ou gnaisse ocelar, esta rocha aflora em morros da região central e da zona sul da cidade do Rio de Janeiro, sendo o litotipo dominante em Niterói. Popularmente conhecida como pedra-de-galho no século XIX, o gnaisse facoidal é referido como granito na maioria dos textos históricos, denominação esta justificada pela sua composição modal e que remete a natureza do protólito.

A origem do "gnaisse facoidal" é discutida desde os primeiros trabalhos sobre a geologia da Cidade do Rio de Janeiro. A maior parte das referências considerava essa rocha um granito metamorfizado. Entretanto, na década de 1960, com a apresentação do mapa geológico, em escala 1:50.000, por Helmbold et al (1965) e com base nos modelos evolutivos geossinclinais em voga, essa rocha foi inserida em um conjunto de origem sedimentar e incluída na denominada Série Inferior, representando uma sequência molassoide (Helmbold et al. 1965; Leonardos 1973). Posteriormente, na década de 1980, trabalhos de mapeamento de detalhe privilegiando as áreas 
da zona sul e norte da cidade, permitiram uma reinterpretação do posicionamento estratigráfico e da origem desta rocha, indicando caráter intrusivo desta rocha na sequência de rochas sedimentares. A partir de então, ele passa a ser interpretado como um ortognaisse de composição granítica a granodiorítica, com idade associada ao ápice da deformação que afetou o orógeno Ribeira (Porto Jr. 1994; Porto Jr. 2004).

\section{A participação das pedreiras no desenvolvimento urbano}

O padrão geológico e geomorfológico da Cidade do Rio de Janeiro, rodeada por grandes maciços rochosos que se sobrepõem a uma baixada alagadiça, fez com que a cidade, desde a sua origem, tivesse uma forte relação de dependência com as pedreiras, cujos produtos eram utilizados como material de construção, pavimentação e em ornamentos de fachadas. Crescendo sobre mangues e charcos, a cidade buscava nos morros adjacentes a matéria-prima para aterros e edificação de suas casas. As características dos terrenos alagados da baixada, ricos em matérias orgânicas e impróprios para uso em obras, tornavam as rochas o material mais adequado para uso em construções, apesar das dificuldades envolvidas na sua extração, transporte e manuseio. Este uso contrastava com a técnica portuguesa, então usual na maior parte do Brasil Colonial, em que predominavam construções de paredes em taipa, baseada na modelagem de solo úmido. Segundo Fernandes (2008), o Brasil é o país da América Latina com o maior número de edificações históricas erguidas em taipa, pois no período colonial, o uso de rochas limitava-se aos componentes da construção, como colunas e pilastras, ou tinham apenas função estética, compondo molduras de portas e janelas que, na forma de cantarias, demandavam mão-de-obra especializada. $\mathrm{O}$ mesmo não acontecia no Rio de Janeiro, onde as rochas compunham não apenas cantarias decorativa, mas eram usadas na estruturação dos edifícios. Em seus textos, o missionário americano Kidder (1857) impressiona-se com a eficiência da técnica de construção em taipa praticada em São Paulo e que contrastava com o método aplicado no Rio de Janeiro, onde as casas eram compostas por fragmentos de rochas cimentadas com argamassa, formando paredes espessas como "fortalezas".
São vários os textos históricos que falam sobre a importância das rochas nas construções da região metropolitana. Azevedo (1877) e Mello Morais (1886) informam a respeito de registros oficiais sobre exploração de pedreiras já no início do século XVII, quando religiosos do Convento do Carmo obtiveram autorização formal do governo para explorar as rochas da Ilha da Enxada para uso em obras do convento e de sua nova igreja. Posteriormente, a transformação da cidade em capital do país, em 1763, promoveu uma aceleração do crescimento urbano, aumentando a importância das pedreiras como fonte de matéria prima. Textos de viajantes que passaram pela cidade durante o século XVIII discorrem, com grande frequência, sobre a singularidade das casas construídas "em pedra" na metrópole carioca, como pode ser constatado nos relatos de François de Parscau, em 1711; John Byron, em 1767; James Cook, em 1768; Aguirre e Langstedt, em 1782, e Jonh Barrow, em 1792, transcritas por França (2000).

Além das casas de moradia, grandes marcos históricos da cidade, como o Aqueduto da Lapa, o Paço Imperial e antigas igrejas (Fig. 1), foram levantadas com blocos de rochas. Staunton, em passagem pelo Rio em 1792 (França 2000), fala sobre o "grande cais de granito, construído em frente ao palácio", cujo "granito extraído de uma pedreira nas redondezas, é o mesmo utilizado para erguer a maior parte das moradias" (Fig. 2). Barrow, além de referir-se ao cais de pedra, também se admira com a qualidade do chafariz situado defronte à escada principal do cais: "O palácio, o obelisco e o dique, foram todos construídos com blocos de granitos bem talhados; a superfície do cais foi pavimentada com a mesma pedra e coberta com areia de sílica." E

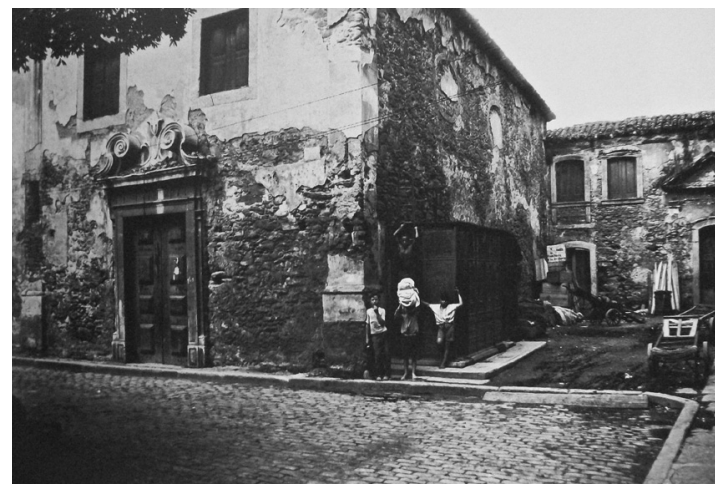

Figura 1. Igreja de São Domingos, situada no largo do mesmo nome, em 1928. Construída em 1791, foi demolida para abertura da Av. Presidente Vargas. Situava-se defronte à atual Av. Passos. Foto de Augusto Malta, extraída de Ermakoff (2009) 


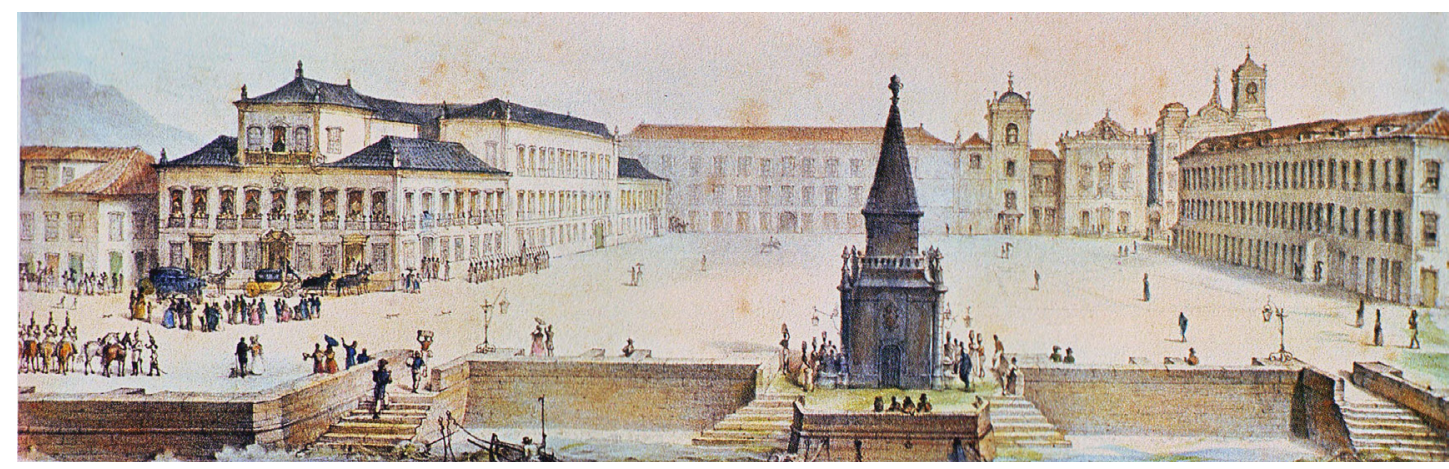

Figura 2. Cais do paço Imperial (atual Praça XV), construído com blocos de gnaisse facoidal, em pintura de Debret (1835). No centro, em primeiro plano, Chafariz do Paço; à esquerda, o Palácio do Paço; em último plano, Igreja da Sé e Convento do Carmo

sobre as ruas da cidade: "as principais são pavimentadas nos dois lados com largas pedras de granito."

A predominância do uso de rochas como a principal matéria prima utilizada em construções mantêm-se em textos do século XIX. Neste novo século, as rochas passam a ser usadas de forma mais efetiva no calçamento da cidade, graças às melhorias urbanas advindas da chegada da Família Real Portuguesa. Durante o reinado presidido no Brasil por Dom João VI, entre 1808 e 1821, o calçamento das ruas era feito "a partir de pedras extraídas dos flancos nus dos morros de granito" (Lima 1908), intensificando as atividades nas pedreiras ao redor da região metropolitana.

Relatos de viajantes e pesquisadores ilustram a intensidade destas extrações. Von Pix \& Von Martius (1824) observam que, naquele período, as casas da cidade ainda eram feitas com blocos de granito, assim como o calçamento da maioria das ruas, ocorrendo frequentes explosões de rochas pelo uso de pólvora em vários pontos da cidade. Kidder \& Fletcher (1857) expressam sua admiração pelo calçamento da Rua Direita, no centro do Rio de Janeiro (atual Primeiro de Março, Fig. 3), a qual compara às ruas mais bem pavimentadas de Londres e Viena. Ao observar a reposição do calçamento removido por uma forte ressaca, em 1853, Kidder lamenta a lentidão do trabalho, levado a cabo por escravos pelo método "three-men-beetle", descrito por Shakespeare no século XVI. Ao ritmo de uma canção, três escravos erguiam um pesado martelo de ferro e, no compasso da música, socavam a rocha no solo, descansando alguns momentos após o extremo esforço (Fig. 4).

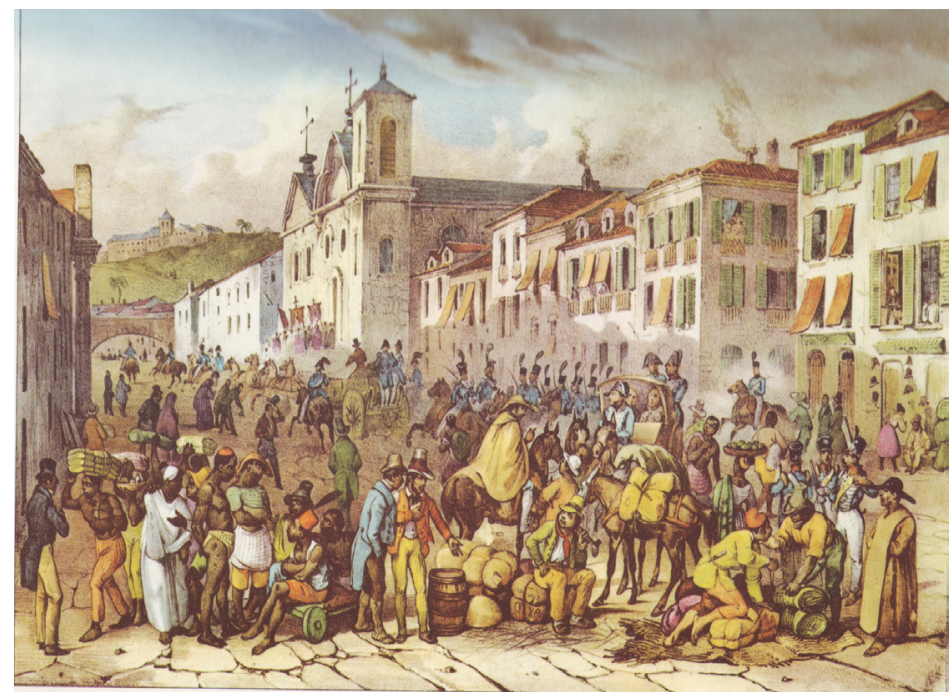

Figura 3. Aspecto da Rua Direita, atual Primeira de Março, em pintura de Rugendas (1889). Em primeiro plano, destaca-se o pavimento, cuja qualidade era comparada às ruas mais bem pavimentadas de Londres. À esquerda, ao fundo, o Morro do Castelo, derrubado durante a gestão do prefeito Pereira Passos. Destaque para a Igreja do Carmo, também ilustrada na figura 2

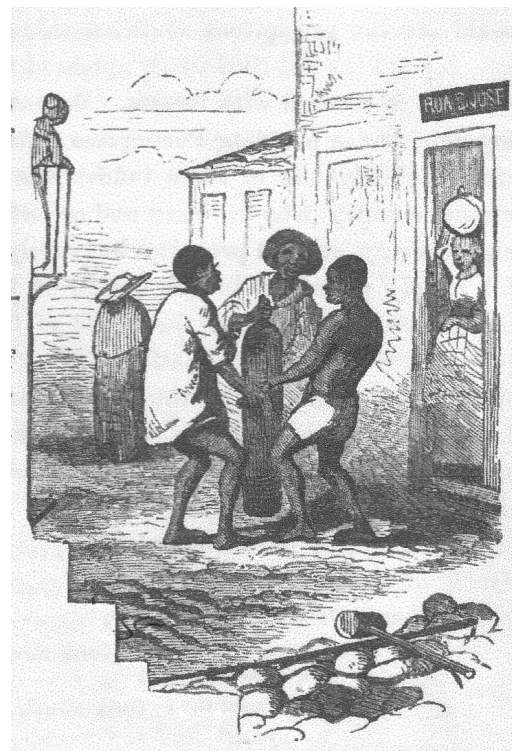

Figura 4. Calçamento por three-manbeet/e nas ruas do Rio de Janeiro. Figura extraída de Kidder (1857) 


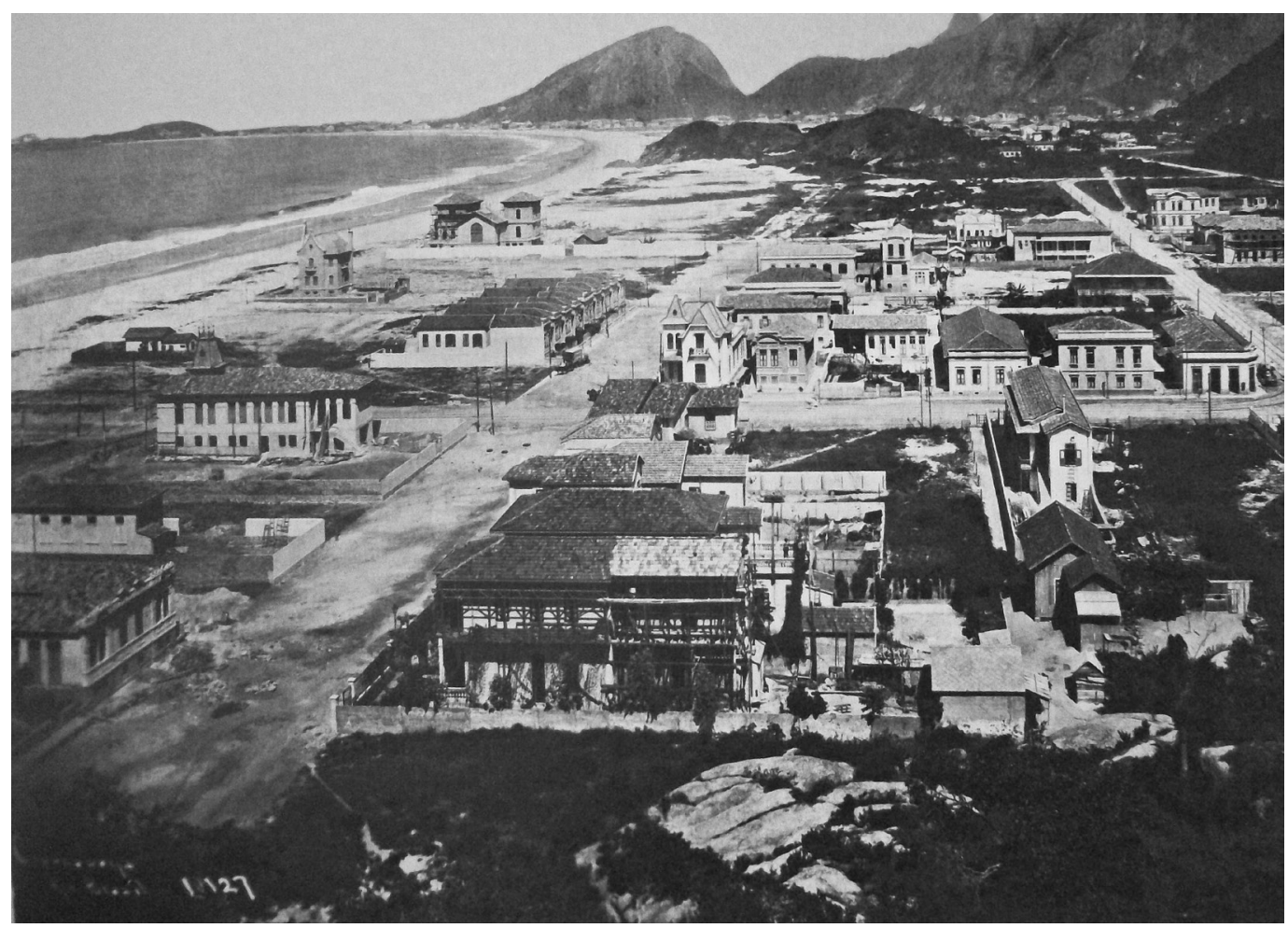

Figura 5. Copacabana, em 1910, antes da remoção da pedreira situada no Morro do Inhangá que se projetava em direção ao mar. Em primeiro plano, Praia do Leme. Atualmente destruída, esta pedreira justificou a mudança no traçado da Av. Nossa Senhora de Copacabana, cujas plantas, datadas de 1900, definiam uma via contínua até o final do Leme (Gérson 2000). Foto de Augusto Malta, extraída de Ermakoff (2009)

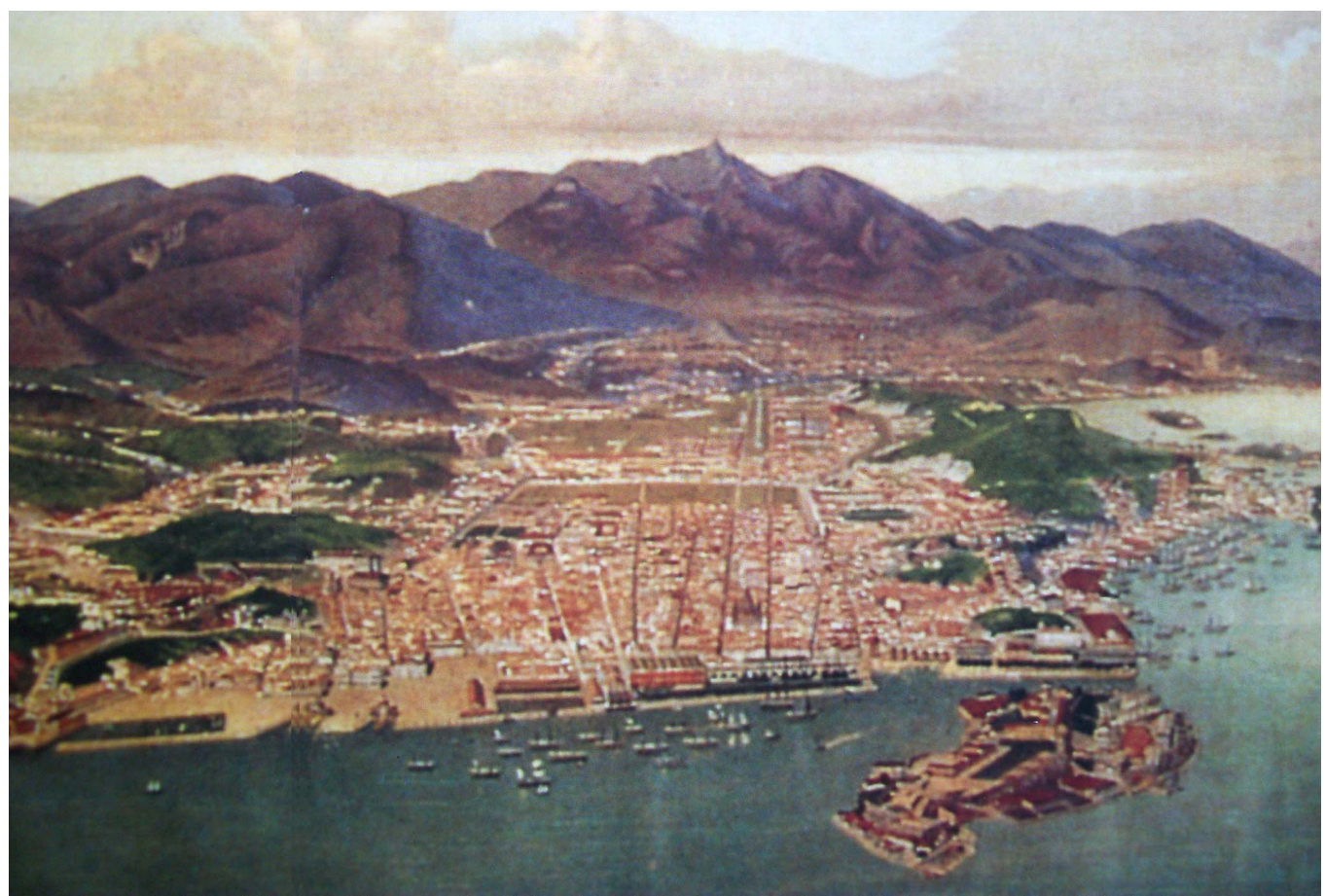

Figura 6 . Detalhe do painel Panorama do Rio de Janeiro em 1873 por Emil Bauch, imagem do Instituto Geográfico e Histórico Brasileiro in Sendyk (2000). À direita, veem-se as escarpas das pedreiras do Morro da Providência. À esquerda, de baixo para cima, os Morros do Castelo, de Santo Antônio e de São Carlos. Entre as duas sequências de morros, a planície aterrada ao longo da qual corre a Av. Presidente Vargas 


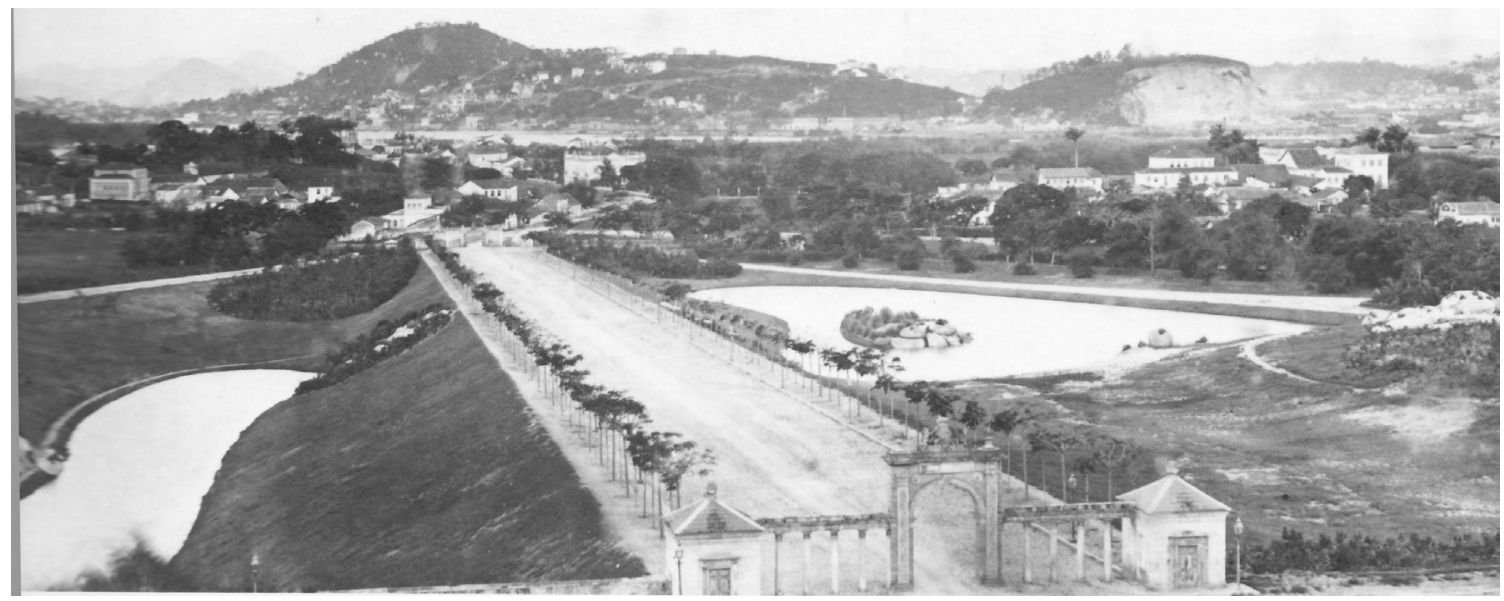

Figura 7. Vista da pedreira de São Diogo (Morro da Providência) a partir da entrada do palácio da Quinta da Boa Vista em 1876 (Lago \& Lago 2008)

Com a vinda da Coroa Portuguesa, em 1808, o crescimento urbano ganhou novo impulso e as pequenas frentes de extração abertas em diversos pontos da cidade foram expandidas a fim de atender a uma maior demanda. É, portanto, no século XIX que as regiões centrais e sul da cidade atingem o apogeu da extração de rochas que, sob um regime de exploração intensiva, chega a zonas então distantes, como Copacabana (Fig. 5).

No entorno do Morro da Conceição, situado entre a atual Avenida Presidente Vargas e a Zona Portuária, desenvolveu-se um grande complexo de

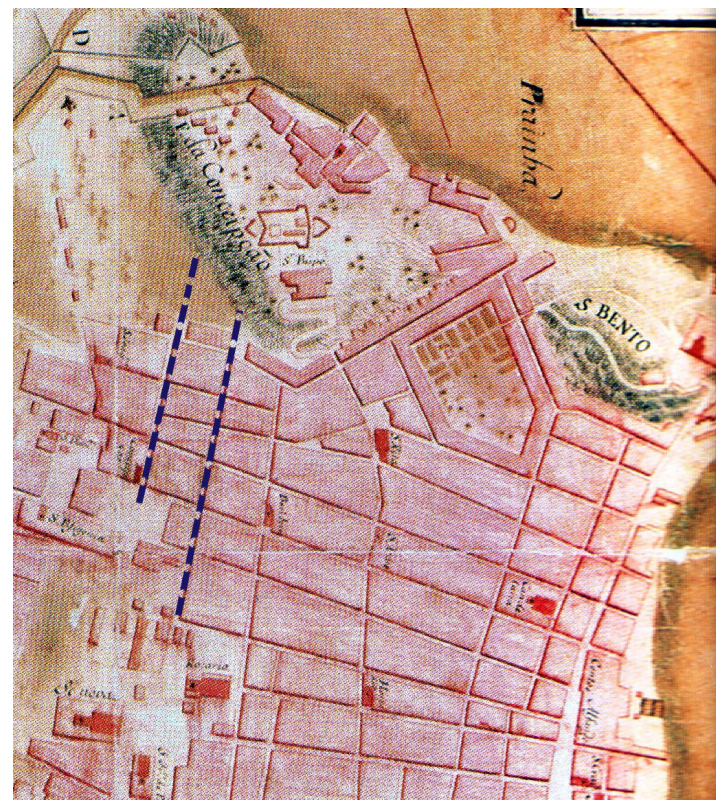

Figura 8 . Traçado das Ruas da Pedreira do Aljube (atual Rua dos Andradas) e da Pedreira da Conceição (atual Rua da Conceição) em mapa de 1729, atribuída a José Custódio de Sá Faria. Sendyk (2000) extração com frentes conhecidas como São Diogo, Valongo, Livramento e Providência, de acordo com as denominações dadas às diferentes porções do conjunto rochoso (Figs. 6 e 7). A dimensão deste complexo, cuja explotação prolongou-se até o final da década de 1960, atesta sua importância como fonte de matéria-prima na metrópole em expansão.

De grande impacto visual, estas extrações influenciavam diretamente na constituição do traçado urbano e no modo de ocupação da cidade, intensificando a circulação de pessoas e veículos ao seu redor. Caminhos utilizados como vias para o transporte do material retirado das pedreiras foram, gradativamente, convertidos em ruas urbanizadas. No centro da cidade, por exemplo, a Rua dos Andradas, cuja primeira designação era "Rua da pedreira do Aljube", fazia a conexão do núcleo urbano com a pedreira, localizada nas proximidades da prisão do Aljube. A mesma função tinha a atual Rua da Conceição, então designada "Rua Pedreira da Conceição" por ser a via de transporte de rochas do Morro da Conceição para o largo de São Francisco, onde estava sendo erguida a Igreja de São Francisco de Paula (Fig. 8). Ambas as ruas eram ligadas pelo Beco das Pedreiras, atual Júlia Lopes de Almeida (Gerson 2000).

Ainda na zona central da cidade destacava-se a pedreira do Morro de Santos Rodrigues, situado entre os bairros de Catumbi e Mata-Porcos (atual Estácio de Sá), nos arredores da Casa de Correção, posteriormente Presídio Frei Caneca (demolido em 2010), que explorava suas pedras para uso nos muros e obras da prisão utilizando os detentos como mão-de-obra (Kiddler \& Fletcher, 1857). A pedreira do Morro do Barro Vermelho (atual 


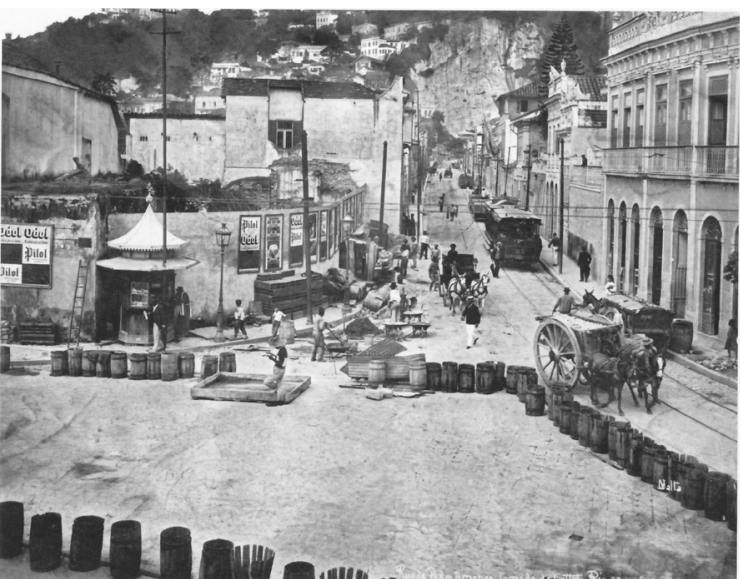

Figura 9. Rua Pedro Américo, com pedreira ao fundo em 1906. Foto de Augusto Malta extraída de Ermakoff (2009)

Morro de São Carlos), também estava incluída nos terrenos adquiridos para construção da nova penitenciária e o papel da pedreira no dia a dia do presídio é relatado por Araújo (2009).

A região da Glória, próxima ao centro da cidade, também se destacava como área de exploração. Nela localizava-se a antiga Rua da Pedreira da Glória (atual Pedro Américo, Figura 9) e a Rua Pedreira da Candelária (atual Bento Lisboa), fornecedora de rochas para a construção da Igreja da Candelária. No detalhe dos mapas do século XIX (Fig. 10), estas ruas ainda aparecem com suas antigas designações. Uma licença oficial para exploração

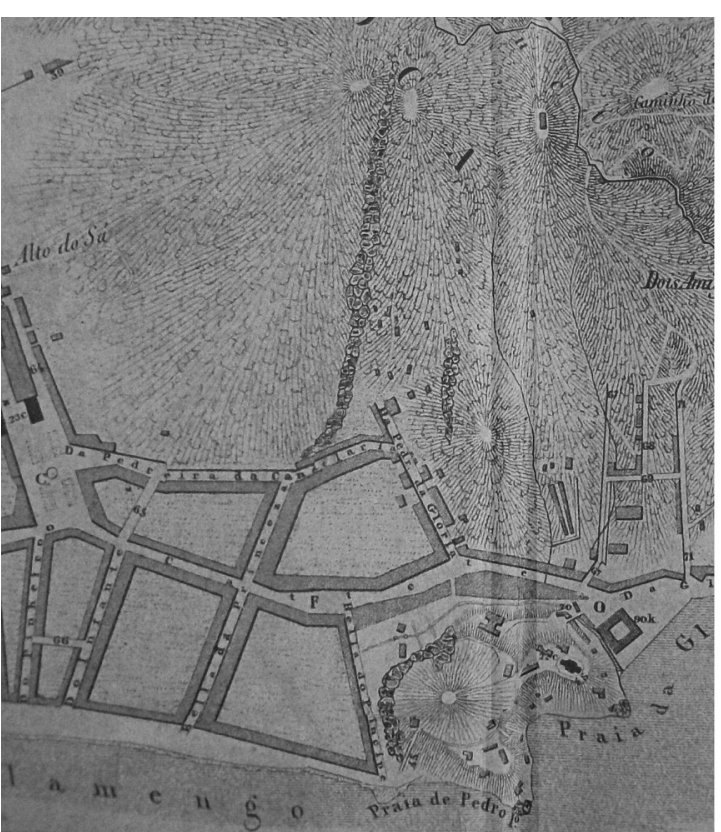

da Pedreira da Candelária foi obtida por religiosos da Irmandade do Sacramento ainda no século XVIII, quando estes, em 1775, decidiram ampliar sua igreja, dando início a obras que se prolongaram por mais de um século. Devido à denominação desta pedreira, bondes que circulavam no Largo do Machado, nos primeiros anos do século XX, traziam a tabuleta "Candelária", o que a muitos intrigava, em função desta igreja estar distante de seu itinerário (Coroacy 1988). Nesta área também havia uma antiga pedreira situada entre os pés da Igreja Nossa Senhora da Glória e o mar (Fig. 11) que, juntamente com as pedreiras localizadas ao pé do Morro do Corcovado, no Catete (Fig. 12), forneciam "gnaisse porfirítico para uso em cantaria”. A própria Igreja da Glória, erguida a partir de 1713, no local onde antes havia a ermida de Antonio Caminha, foi construída "servindo-se do granito de uma das pedreiras da vizinhança" e que, ao final do século XIX, ainda forneciam "as melhores pedras de cantaria da cidade" (Azevedo 1877).

Segundo Gerson (2000), uma das pedreiras da Glória seria propriedade do Conde D'Eu, que na sua parte arrasada, construiu casas populares de aluguel, compondo o cenário descrito por Artur de Azevedo em seu romance $O$ cortiço, publicado em 1880. Na obra, os personagens e seus dramas estão ligados à uma pedreira adjacente a um cortiço, de onde o personagem João Romão obtêm, por meio

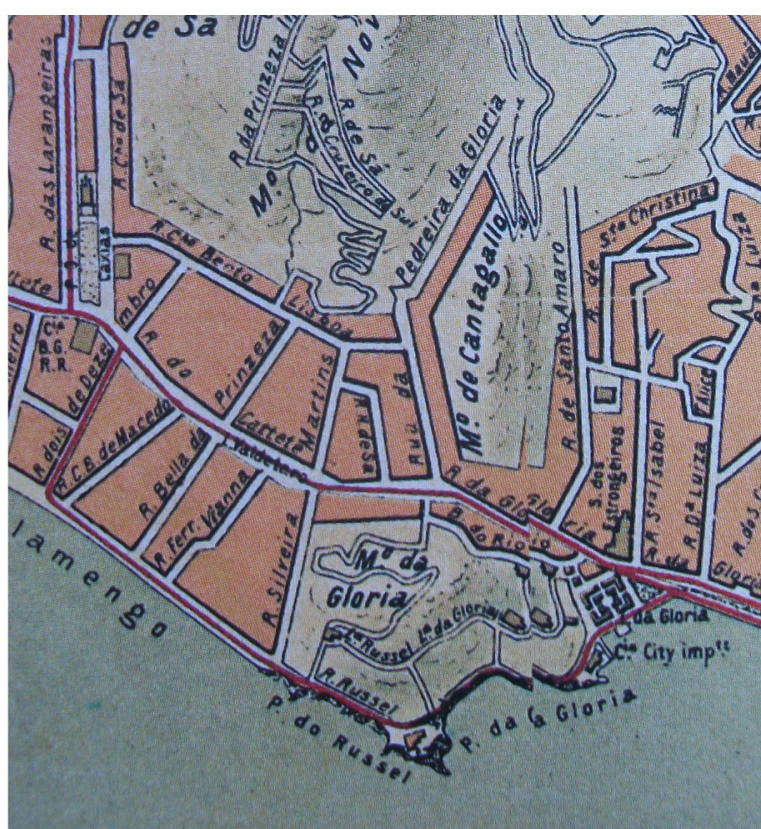

Figura 10. Rua Pedreira da Candelária (atual Bento Lisboa) e Rua Pedreira da Glória (atual Pedro Américo) na região de Glória e Flamengo. À direita, mapa de 1838. À esquerda, Planta do Rio de Janeiro, 1894, publicada por A. Meriam Editora (2006), com blocos estilizados assinalando o local com pedreiras. A comparação entre as duas imagens permite a visualização do avanço das ruas sobre as franjas das pedreiras 

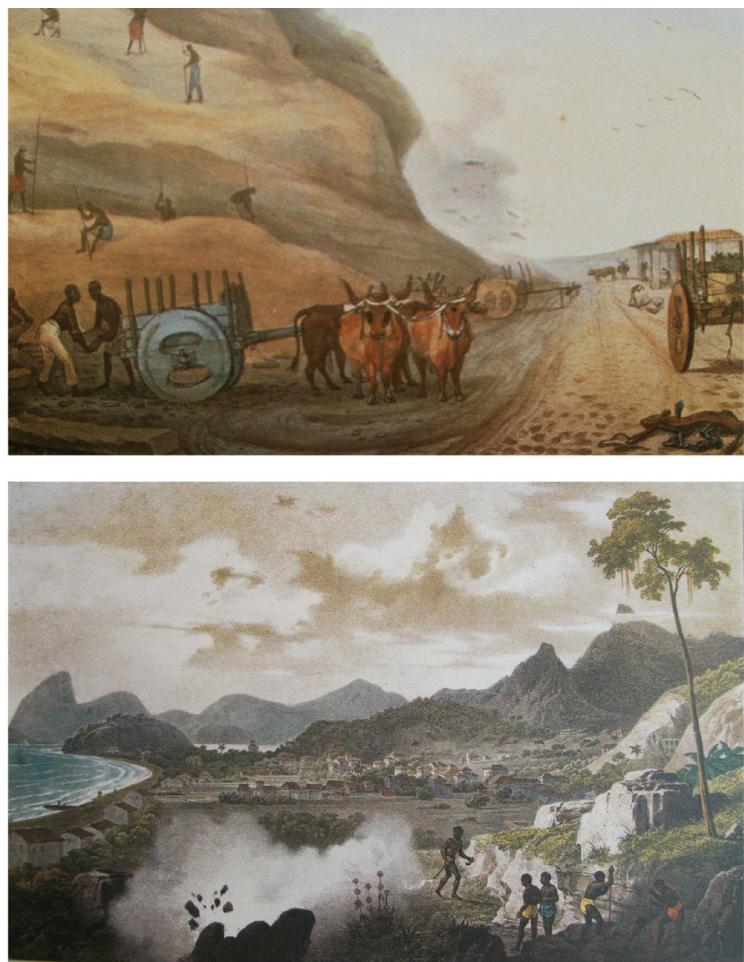

Figura 11. Pedreira da Glória, na frente de extração voltada para a praia. No topo, olhando em direção a Enseada da Glória, escravos perfuram a rocha para introdução de explosivos (por Debret 1835). Abaixo, olhando em direção à Praia do Flamengo, vê-se ao fundo o Morro da Viúva (por Rugendas 1889) da retirada de lajedos e paralelepípedos, a renda necessária para a construção do conjunto habitacional que faz jus ao título do romance. A obra de Azevedo também encontrava paralelo no conjunto habitacional da região do Morro da Providência, pois foi na base deste morro que se desenvolveu o mais populoso cortiço da cidade, conhecido como "Cabeça-de-Porco", que, tendo início na rua Barão de São Felix, na altura da Bento Ribeiro, prolongava-se até a frente de pedreira conhecida como Cajueiros (Coroacy 1988). Zylberg (1992) informa que alguns dos terrenos que constituíam o Cabeça-de-Porco também eram tidos como propriedades do Conde D'Eu, alcunhado de “o corticeiro" por jornais da época (Schwarez 1999).

Dentre as diversas pedreiras da zona sul, destacava-se a do Morro da Viúva (também denominado, em diferentes períodos de Morro do Leripe e Morro do Flamengo), uma das mais antigas pedreiras da cidade, situada entre os bairros de Botafogo e Flamengo (Fig. 13). Seu primeiro registro oficial data de 1618, quando monges do Mosteiro de São Bento solicitaram à Câmara a concessão de vinte braças de pedreira no morro, então conhecido como Morro do Leripe, para uso das pedras nas obras de sua igreja, iniciada em 1633 (Gerson 2000). Em 1891, foi construído um reservatório em seu

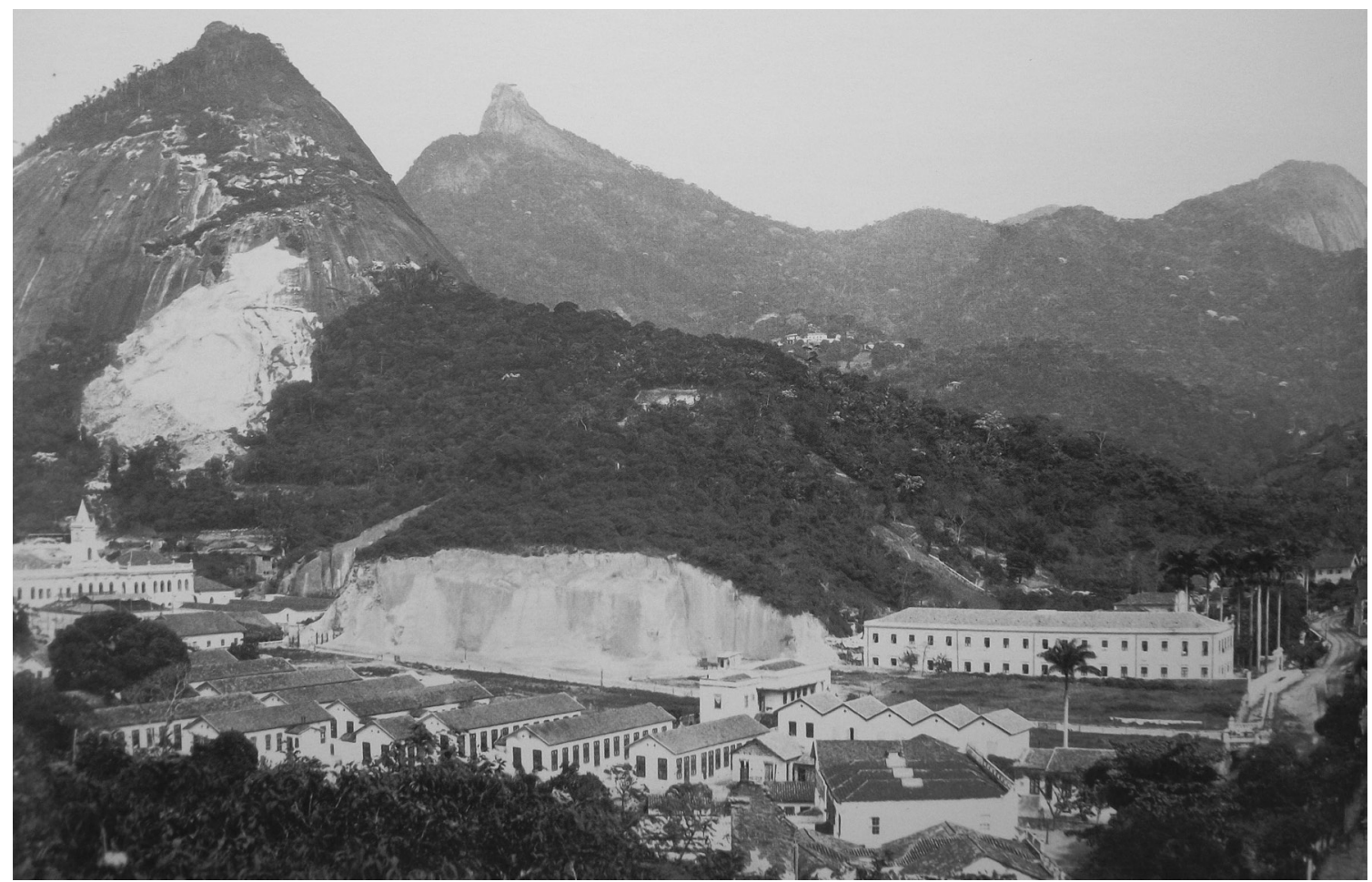

Figura 12. Rua General Glicério, Laranjeiras. Foto de Juan Gutierrez, 1894. Extraída de Ermakoff (2006) 


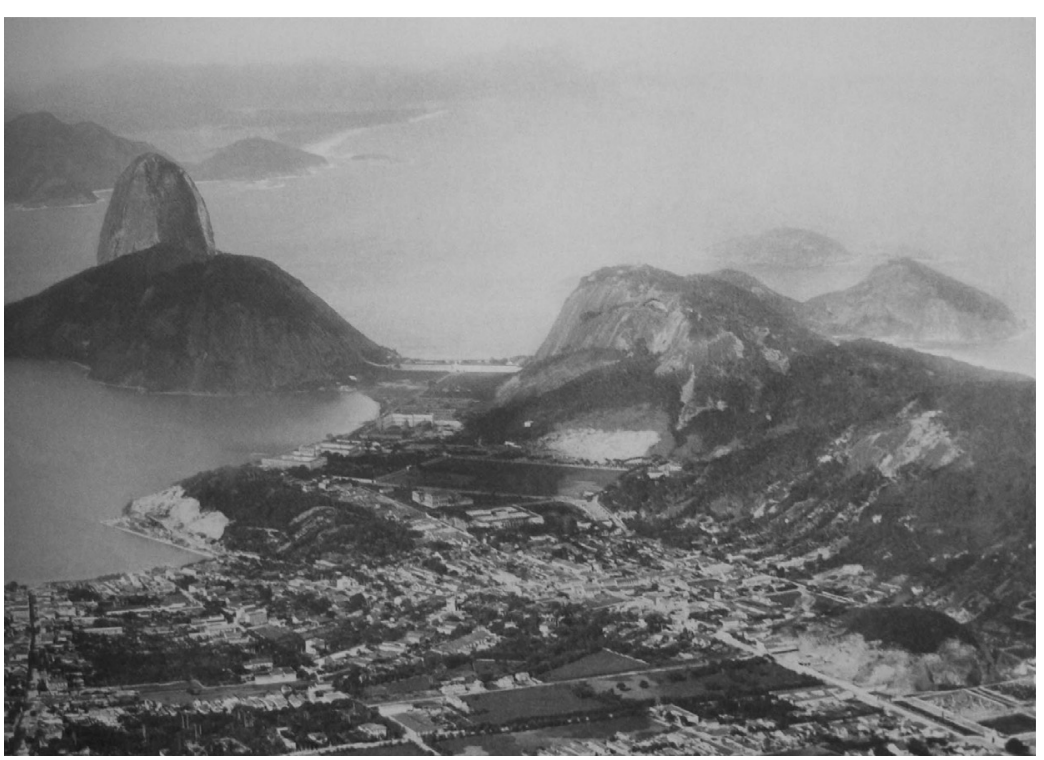

Figura 13. Vista de Botafogo, com pedreiras do Pasmado, a esquerda, e da Babilônia, a direita. No canto direito, em primeiro plano, pedreira do cemitério São João Batista, em foto de Mark Ferrez, 1889 In Lago \& Lago (2008)

dos por imigrantes, às classes mais abastadas, passando pelos concessionários da mineração, construtores, artesãos, comerciantes e órgãos públicos. De outro lado, as pedreiras também influenciavam no desenho da malha urbana, dando origem a novas vias, ao redor das quais eram erguidas casas para moradia e comércio e liberando espaços pelo aplainamento das franjas dos morros, que passam a ser ocupadas por uma população de baixa renda, tanto na região central, como na zona sul da cidade, onde eram extraídos gnaisse facoidal e leptinito, materiais mais adequados à cantaria do que os topo com o objetivo de distribuir água nos bairros de Botafogo, Praia Vermelha e Leme.

$\mathrm{O}$ que se constata no conjunto de citações históricas, é a importância das pedreiras durante o século XIX, no contexto econômico e social da cidade, atingindo diretamente todas as camadas da população, desde os escravos que trabalhavam na extração da rocha, posteriormente substituí-

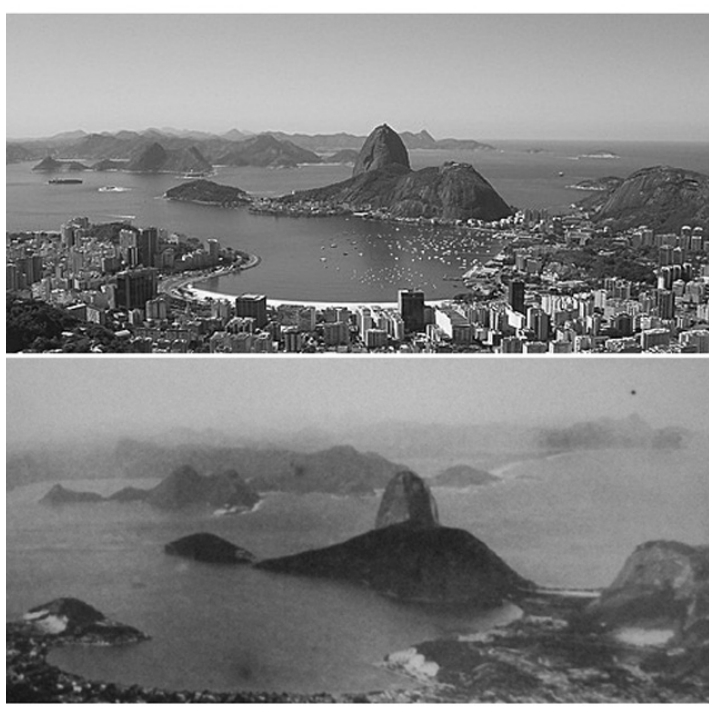

Figura 14. Enseada de Botafogo com seu aspecto atual e em 1880, em foto de Mark Ferrez (in IMS 2005). As frentes de extração que, outrora provocavam forte impacto visual, hoje estão ocultas por grandes edifícios que bloqueiam visualmente as feições naturais gnaisses do Morro da Conceição.

Na entrada do século XX, as pedreiras continuaram compondo a paisagem urbana. A cidade entra em uma nova fase de expansão e reformas urbanas seguindo o projeto de remodelagem traçado pelo governo. Ruas são destruídas, monumentos históricos são postos abaixo e largas avenidas substituem as estreitas ruas do período colonial. Dennis (1911), em sua passagem pelo Rio de Janeiro, neste período, descreve a cidade como uma planície rodeada por morros de granito arrasados por picaretas e cargas de explosivos.

O crescimento da cidade durante as décadas de 1950 e 1960 deu-se principalmente no eixo sul-norte, com valorização, cada vez maior, das áreas da zona sul, onde muitas pedreiras estavam localizadas. A legislação restritiva e o aumento do valor dos terrenos que elas ocupavam fez com que as pedreiras fossem deslocadas para áreas que, na época, eram distantes do centro de desenvolvimento da cidade. Assim, as atividades de extração foram deslocadas para a então denominada Zona Rural, que englobava áreas não mais do Maciço da Tijuca, mas sim do Maciço da Pedra Branca e dos bairros de Jacarepaguá, Recreio, Bangu, Santa Cruz e Guaratiba.

Algumas das pedreiras que para lá se deslocaram levaram junto os seus nomes originais. Assim, na região da Curicica, Jacarepaguá, instalou-se a pedreira Copacabana, originada da zona sul da 


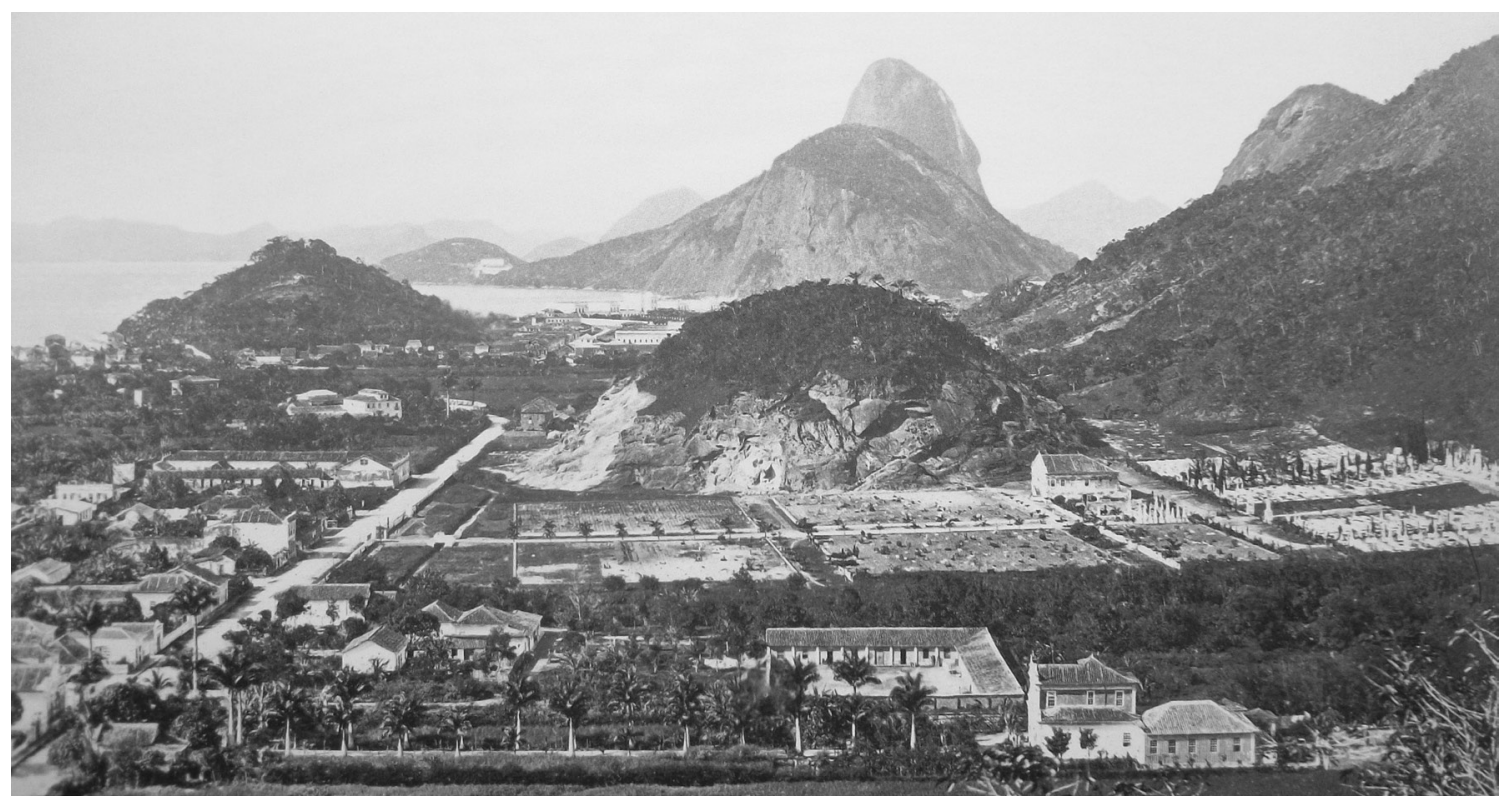

Figura 15 - Pedreira do Cemitério São João Batista em 1865. Apenas uma pequena porção do corpo original encontrase hoje preservada. Leuzinger in Ermakoff (2009)

cidade e a seu lado a pedreira Tamoios, originada na zona da Leopoldina, zona norte da cidade. Hoje, com o contínuo crescimento da cidade e a transformação destas áreas em zonas de ocupação urbana intensa e valorizada, estas mesmas pedreiras estão em processo de fechamento e suas atividades sendo deslocadas para as áreas limítrofes do município.

$\mathrm{Na}$ paisagem atual, a grande maioria das frentes de pedreira da região central e zona sul do Rio de Janeiro está oculta por grandes edifícios e/ou situadas em áreas de difícil acesso (Fig. 14), seja por estarem localizadas em propriedades privadas ou em áreas de risco, eventualmente controladas por facções criminosas. Em alguns casos, como no Morro da Viúva, Morro da Glória e na pedreira do Cemitério São João Batista (Fig. 15), o desgaste do volume original foi bastante acentuado.

\section{Estudo de caso: 0 conjunto arquitetônico do Rio Antigo}

A preservação de vários edifícios históricos e a localização das antigas pedreiras, em áreas hoje urbanizadas, torna a região central do Rio de Janeiro rica em exemplos sobre a relação histórica de uso da rocha pelo homem, pois, apesar das grandes obras realizadas pelo prefeito Pereira Passos no início do século XIX, responsáveis por transformações urbanas radicais e pela destruição do berço histórico da cidade, no Morro do Castelo e, apesar, também, da explosão imobiliária que se seguiu ao processo de modernização, dando origem aos grandes arranha-céus, o centro da cidade ainda preserva um conjunto arquitetônico que abrange as ruas pertencentes ao "Rio Antigo", onde estão preservadas várias construções erguidas com materiais extraídos das pedreiras históricas do centro e da zona sul da cidade.

Os arredores da Igreja da Candelária, em particular, possuem vários exemplos esclarecedores da relevância do uso de rochas na evolução da cidade. Situada no cruzamento das duas mais importantes avenidas que cortam o centro da cidade (Avenidas Rio Branco e Presidente Vargas), a região da Candelária destaca-se, desde o período colonial, como centro econômico e administrativo. Segundo Abreu (2010), as ruas de sua freguesia formavam o verdadeiro centro da cidade em meados do século XIX, com concentração de grande parte do comércio importador e exportador, bancos, consulados e companhias de navegação, motivo pela qual já era privilegiada com o calçamento em paralelepípedos em 1854. A Igreja da Candelária expõe em sua fachada amostras de gnaisse facoidal que interessam não só pelo seu valor histórico e estético, como pelas suas características petrográficas. Construída em 1609, em um local antes ocupado por uma capela, a igreja foi reformada em $1710 \mathrm{e}$ submetida a obras e ampliada entre 1775 e 1885 (Souza 1998). Embora seu interior seja trabalhado com rochas importadas, sua fachada é revestida 


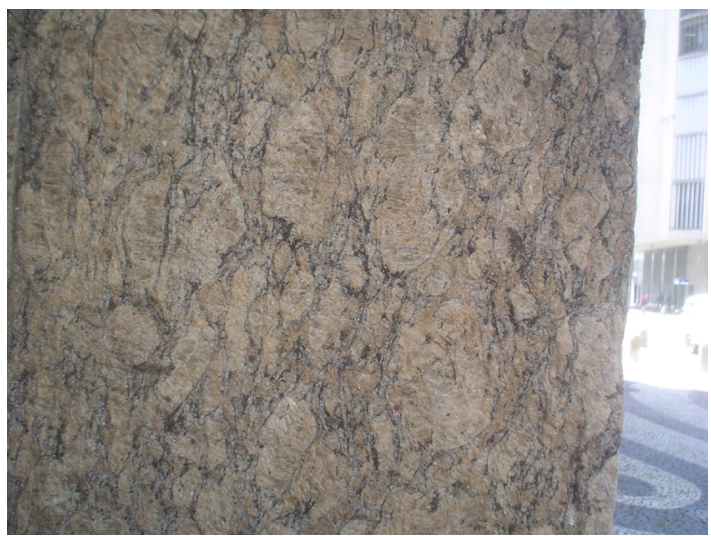

Figura 16. Detalhe de gnaisse facoidal em cantaria da fachada da Igreja da Candelária.

por duas rochas tipicamente cariocas: o leptinito e o gnaisse facoidal, este último também compondo o calçamento ao redor do edifício. $O$ gnaisse que reveste a fachada exibe entre 40 e $50 \%$ de megacristais de microclina rosa, cujos eixos maiores variam de 5 a $10 \mathrm{~cm}$, envolvidos por uma matriz composta por biotita, quartzo, plagioclásio e granada subordinada. A foliação é anastomosada e definida pela orientação planar de biotita que contornam cristais estirados de microclina, textura esta responsável pela denominação pedra-de-galho, usada por nossos antepassados (Figs. 16). As diferentes direções de corte a que foram submetidas estas rochas permitem uma exposição didática do aspecto tridimensional resultante de uma deformação heterogênea (Fig. 16 a 21). O observador, ao analisar os blocos de cantaria, perceberá, além dos efeitos estéticos resultantes da direção de corte, sua influência na percepção da razão megacristais/matriz e, portanto, da possibilidade de erro na estimativa da compo-

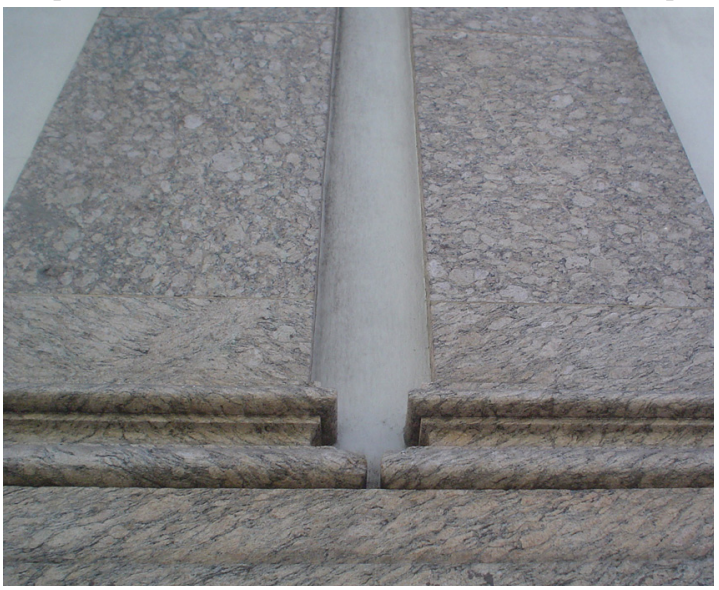

Figura 17. Diferentes planos de cortes do gnaisse facoidal em cantaria da igreja da Candelária.

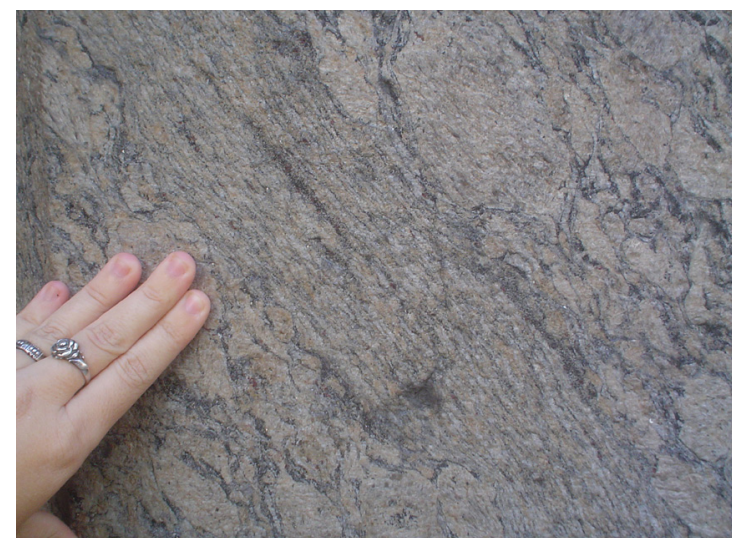

Figura 18. Faixa milonitizada em gnaisse facoidal, Igreja da Candelária: variações texturais resultantes de diferentes intensidades de deformação

sição modal se apenas um plano for considerado. Uma análise dos blocos de cantaria permite, também, constatar os efeitos da atuação de diferentes intensidades de deformação (Fig. 18). Também estão expostos registros das relações entre o gnaisse facoidal e veios, em cantarias com veios de granito equigranular, de granulometria média, exibindo bordas de resfriamento (Fig. 19). As cantarias de leptinito expostas na fachada da Igreja da Candelária são compostas por quartzo, plagioclásio, biotita e granada. É uma rocha de granulação fina, branco acinzentada, com foliação espaçada definida pela orientação de biotita (Fig. 20). Esta é cortada por pegmatitos (Fig. 21) compostos por quartzo, biotita, microclina e granada. Assim como o gnaisse, o leptinito exibe diferentes graus de deformação.

Situada a poucos metros da Igreja da Candelária, a Casa França-Brasil foi inaugurada como Praça do Comércio em 1820 e fechada temporariamente até ser reaberta para sediar a Alfândega, em 1824. O

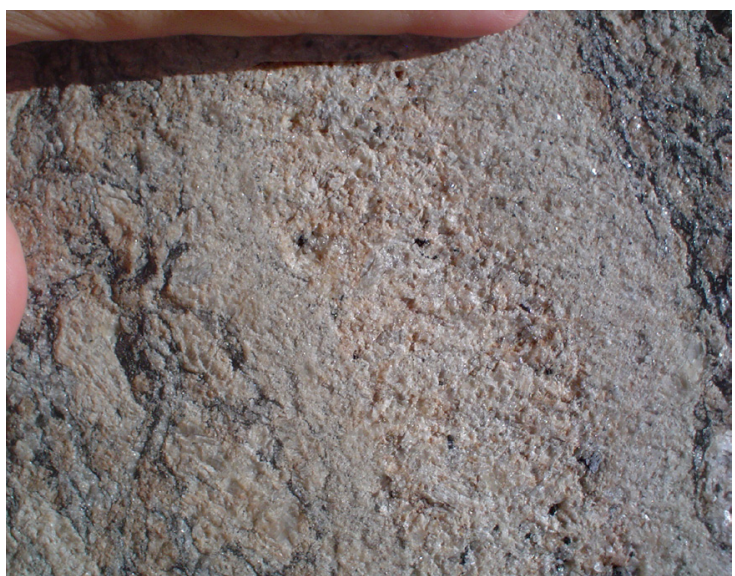

Figura 19. Contraste de granulometria entre bordas e núcleos em veios granítico intruso em gnaisse facoidal 


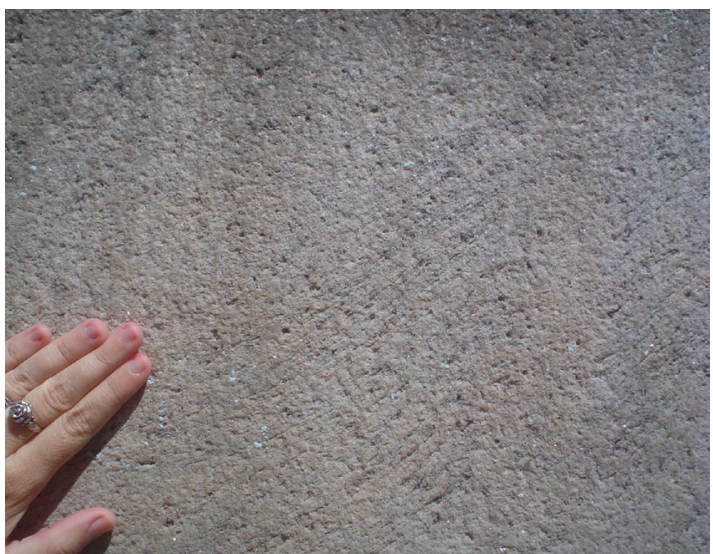

Figura 20. Cantaria de leptinito exposto na fachada da Igreja da Candelária

prédio foi remodelado em 1852, sob orientação de André Rebouças, e tombado em 1938, tendo funcionado como Tribunal do Júri de 1956 a 1978. Na década de 80, foram realizadas obras para instalação da Casa França-Brasil, tendo sido preservado o piso original, com substituição apenas local de pontos deteriorados. A cantaria exposta na área externa do edifício é formada por leptinito (Fig. 22) e gnaisse facoidal com características semelhantes às descritas para os blocos que revestem a Igreja da Candelária.

A poucos metros da Candelária, encontram-se, também, os prédios do Centro Cultural dos Correios, na rua Visconde de Itaboraí, cuja construção foi iniciada em 1875, e do Centro Cultural Banco do Brasil, na avenida Primeiro de Março, cuja construção foi iniciada em 1880. Ambos também são revestidos por gnaisse facoidal com propriedades semelhante aos exemplares da Igreja da Candelária, sendo possível, contudo, observar variações texturais e composicionais (maior deformação, maior conteúdo de minerais hidratados) nas

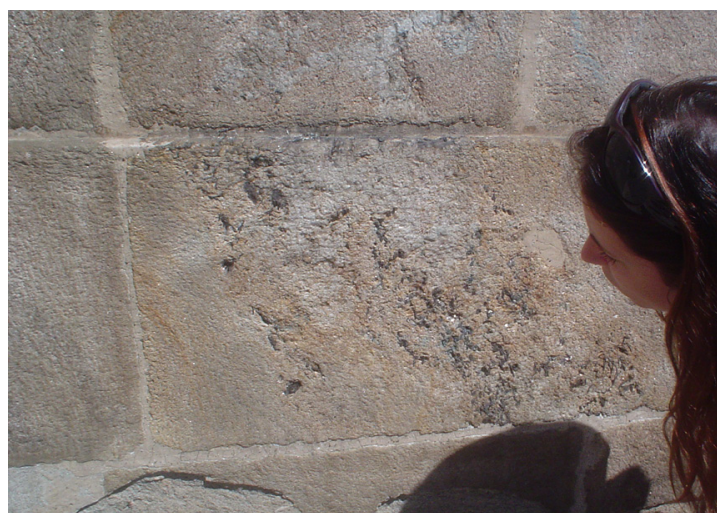

Figura 21. Veio pegmatítico composto por quartzo + microclina + biotita + granada em leptinitos. Igreja da Candelária

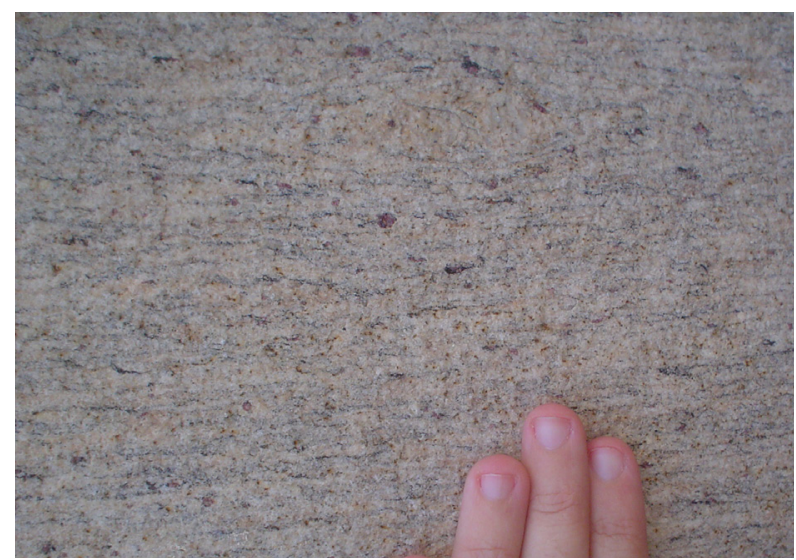

Figura 22. Leptinito em cantaria da Casa França- Brasil

rochas do Centro Cultural dos Correios (Figs. 23 e 24). Ainda nos arredores da Candelária, o gnaisse facoidal reveste a Igreja Nossa Senhora da Lapa dos Pescadores (Fig. 25), inaugurada em 1747 e restaurada entre 1862 e 1872, quando a fachada adquiriu o aspecto atual, e a Igreja Santa Cruz dos Militares (Fig. 26), na Rua Primeiro de Março, construída em 1628 e reformada entre 1780 e 1811. Seguindo-se pelas Ruas do Rosário, do Mercado, Ouvidor e adjacências, o gnaisse facoidal é presença constante nas fachadas dos edifícios, emoldurando portas e janelas. Na Rua do Rosário, n³8, onde atualmente funciona um sebo, é possível observar o uso de blocos de rochas na estruturação das paredes. A rocha predominante é um gnaisse com feldspato porfiroclástico, de matriz de cinza escura e granulometria fina, típica representante dos ortognaisses dioríticos extraídos nos morros da Providência (Fig. 27).

$\mathrm{Na}$ região da Praça XV, antigo Largo do Paço,

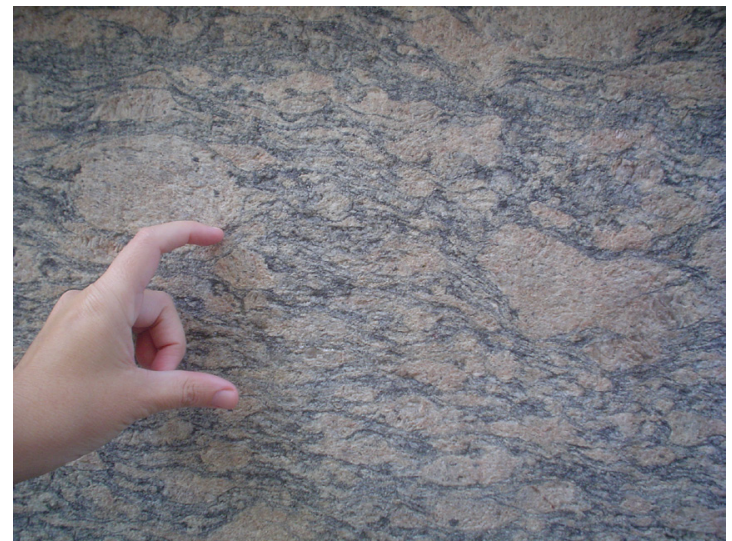

Figura 23. Gnaisse facoidal na fachada do Centro Cultural dos Correios: texturas distintas das cantarias da Igreja da Candelária 


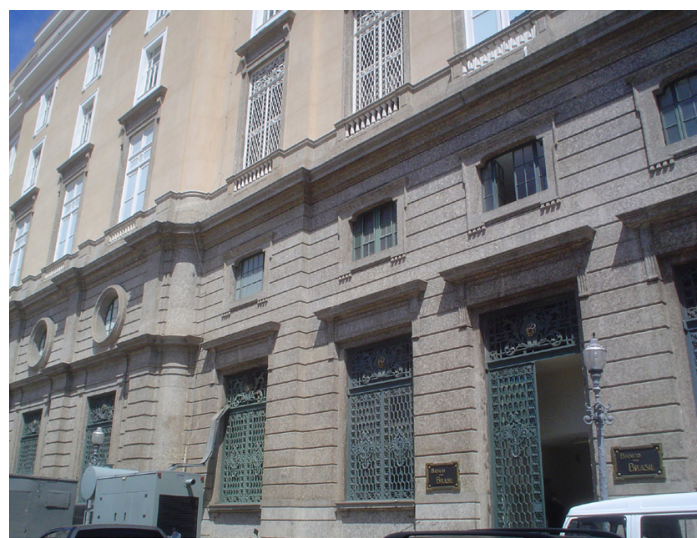

Figura 24. Fachada em gnaisse facoidal do Centro Cultural dos Correios na região da Candelária

vários são os exemplos de utilização de rochas. No centro da praça, está exposto o Chafariz do Paço, lavrado em gnaisse facoidal e que ocupa um lugar de destaque na história do Rio de Janeiro, pois abastecia a população de água no coração da cidade, além dos navios fundeados na baía. Adjacente ao chafariz há porções preservadas do cais também em rocha (Fig. 28), descritos com admiração por viajantes desde o século XVIII. Defronte à praça, estão a Igreja da Sé e o Convento do Carmo anexo, para cuja construção, como dito anteriormente, os carmelitas obtiveram autorização para extrair rochas da Ilha da Enxada, no século XVII. Este conjunto, como se apresentava no século XIX, pode ser visto na Figura 2.

O que restou do Convento do Carmo é sede, atualmente, do Centro Cultural Candido Mendes. Tanto no interior como na fachada do convento e da igreja, é possível distinguir os antigos blocos de cantaria colonial daqueles adicionados em recentes reformas, devido ao contraste existente nas superfícies talhadas a mão e a serra elétrica. A mistura de litologias aqui é maior do que nos edifícios anteriormente descritos. No convento, são vistos leptinitito, com porfiroblastos de granadas, abundantes nas fachadas e compondo arcos internos. Também são observadas cantarias de granito cinza com pórfiros $(3 \mathrm{a} 4 \mathrm{~cm}$ ) róseos de microclina, hoje caracterizado como Granito Utinga (Pires et al 1983). No interior da Igreja da Sé está exposta a estrutura interna de uma parede composta por vários tipos de rochas (gnaisse facoidal, gnaisses cinzas e leptinitos) mesclada com tijolos de barro (Fig. 29). Os arcos internos da igreja também são compostos por uma mistura de gnaisse facoidal e leptinito. O conjunto apresenta, portanto, uma composição mais rústica e desigual quando com-

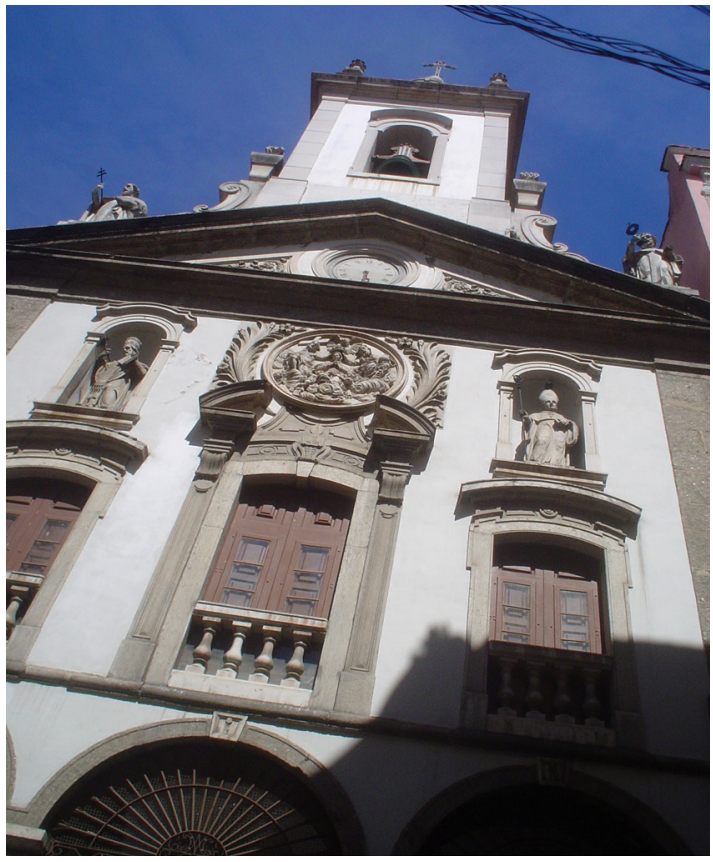

Figura 25. A Igreja Nossa Senhora da Lapa dos Pescadores, na região da Candelária, ornada com cantarias de gnaisse facoidal. Foi erguida no século XVIII e reformada no século XIX

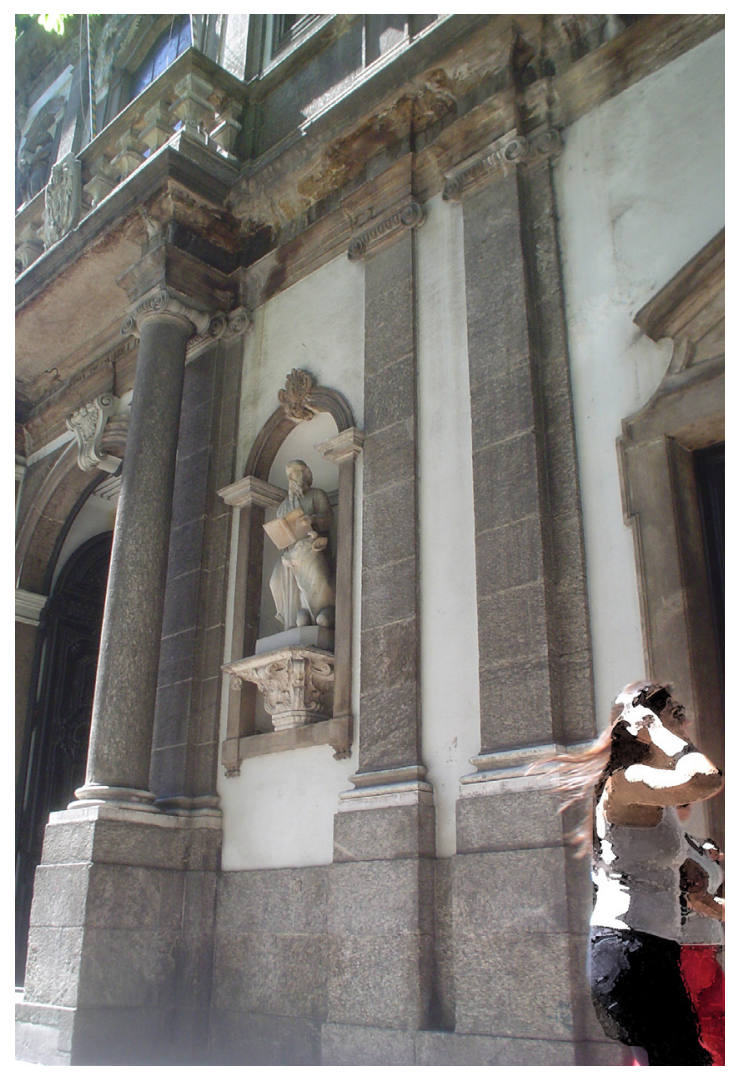

Figura 26. Igreja Santa Cruz dos Militares, na Rua Primeiro de Março, edifício histórico que data do século XVII. Foi reformada durante os séculos XVIII e XIX, ornada com gnaisse facoidal 


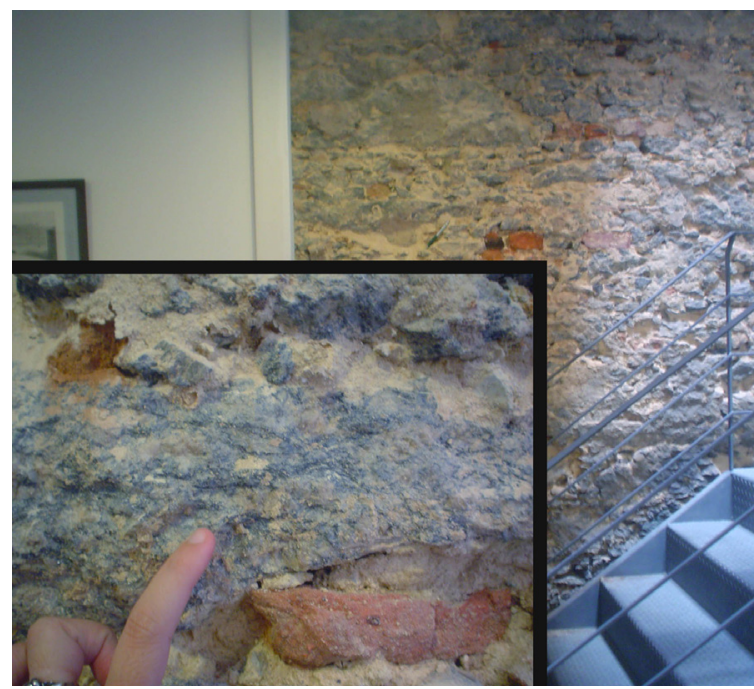

Figura 27. Típica parede erguida com blocos de rocha no Rio de Janeiro Colonial. No quadro menor, detalhe exibindo a rocha predominante: ortognaisse cinza com porfiroclastos de microclina. Rua do Rosário, Centro

parado às cantarias que ornamentam os edifícios mais recentes do século XIX.

$\mathrm{Na}$ Figura 30 são apresentadas as localizações dos logradouros e edifícios mencionados. Estes se situam em áreas de fácil acesso, com infra-estrutura propícia a realização de atividades didáticas. Tomando o Largo de São Francisco como ponto de partida, pode-se seguir pela Rua dos Andradas ou pela Rua da Conceição (antigas Ruas Pedreira do Aljube e Pedreira da Conceição). No final destas ruas é possível observar uma frente de corte da antiga Pedreira da Conceição. A poucos quarteirões, seguindo-se pela Av. Presidente Vargas, chega-se à região da Candelária, onde estão as obras descritas neste trabalho.

A Figura 31 exibe a localização das principais frentes de extração abandonadas entre o centro da cidade (Complexo da Providência) e Botafogo. Ao norte, o alinhamento que compõe Complexo da Providência, formado pelos Morros da Conceição, da Providência, de São Diogo ou do Livramento, conforme denominações locais e de acordo com o período histórico. Pouco ao sul, cruzando a Avenida Presidente Vargas, temos o Morro de São Carlos (ou de São Rodrigues ou Santo Rodrigues), onde estão situadas as pedreiras exploradas pelos presidiários da antiga Casa de Detenção. No centro as diversas frentes da região do Catete e Glória, adentrando pelo Vale das Laranjeiras. O Morro da Viúva marca a divisa das frentes desta região com as pedreiras do Bairro de Botafogo. No extremo sul do mapa, está a localização da antiga pedreira que separava Copacabana e Leme.

Deste conjunto, as pedreiras do Morro da Viúva e as Pedreiras da Candelária e da Glória, constituem as prováveis áreas fontes para as cantarias dos edifícios anteriormente descritos. O Morro da Viúva foi transformado em Área de Proteção Ambiental pela Secretaria Municipal de Meio Ambiente da cidade do Rio de Janeiro em 1998. Este é acessível por escadarias (Fig. 32) que conduzem ao antigo reservatório de água, construído em 1891 para abastecimento da população do entorno por meio de captação de águas do reservatório do Pedregulho, inaugurado em 1880 em São Cristóvão. Assim como os adornos do edifícios que fazem parte do conjunto do reservatório, tais escadarias são do próprio gnaisse facoidal. O núcleo preservado à exploração do Morro da Viúva, que se prolonga por mais de 300 anos, é composto por gnaisses cujo hábito ocelar característico não é constante ao

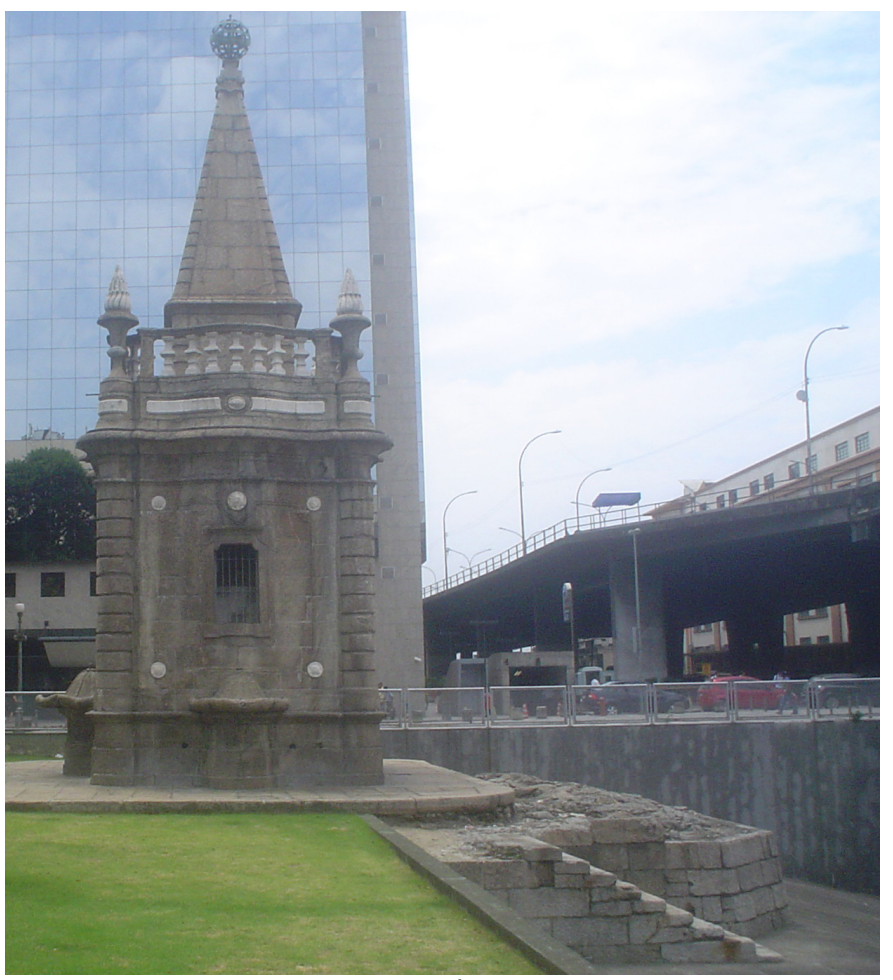

Figura 28. Antigo Chafariz no Paço. À direita, remanescentes do antigo cais de pedra, cujo aspecto original pode ser visto na Figura 2. Praça XV, Centro 


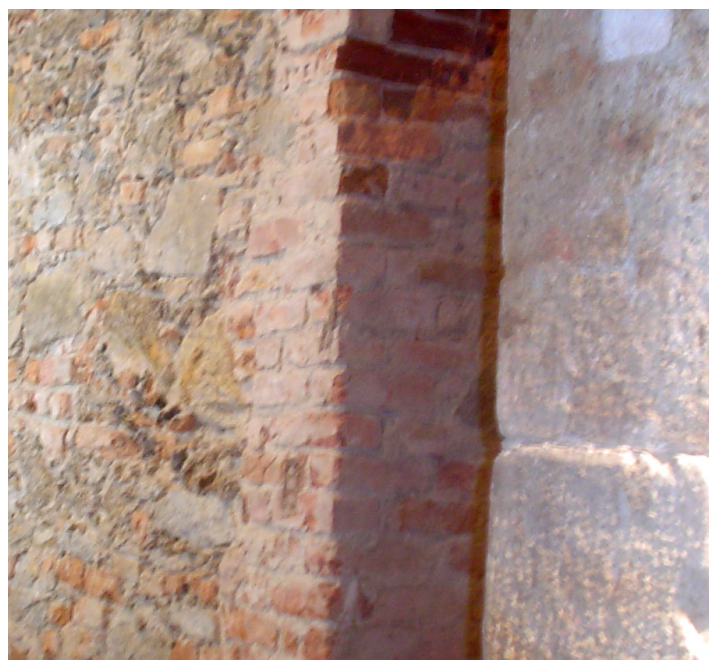

Figura 29. Parede composta por mistura de rochas e tijolos no interior da Igreja da Sé, na rua Primeiro de Março, Centro

longo dos afloramentos, que exibem uma grande variação no grau de deformação da rocha, com megacristais de microclina variando de tabulares a porfiroclásticos (Fig. 33).

As Figuras 34A e 34B mostram o aspecto das pedreiras aos pés do Morro da Cintra, nas proximidades da Pedreira da Candelária, no século XIX. A frente de extração exposta na Rua Marquesa de Santos (Fig. 35) é de fácil acesso, pois uma pequena parte de seu corte se estende ao longo da rua. A rocha aflorante no local é um leptinito leucocrático de granulometria fina, contendo granada, cuja foliação é definida por camadas milimétricas descontínuas de biotitas (Fig. 36). A rocha possui camadas estiradas, nas quais biotita é uma fase acessória ou ausente. Há ocorrência de veio pegmatítico com predominância de microclina e com biotitas de granulometria superior a $10 \mathrm{~cm}$ (Fig. 37), tal qual observado em cantaria da fachada da Igreja da Candelária (Fig. 22).

\section{Conclusões}

A extração de rochas no Rio de Janeiro deve ser compreendida como um processo que extrapola a questão do fornecimento de matéria prima para construção civil, dada a relevância histórica deste tipo de extrativismo na região.

O uso de rochas como principal matéria prima de habitações e demais edifícios, desde a fundação da cidade até o século XIX, era uma característica peculiar à cidade do Rio de Janeiro. Fontes de matéria-prima capaz de gerar empregos e riqueza, as pedreiras tinham conexões com todas as camadas sociais, do escravo ao nobre e sua importância como motor sócio-econômico é retratada na literatura e nos jornais da época. A "rocha" não apenas compõe paredes, mas livra as ruas da lama por meio do calçamento, determina o traçado de ruas, a formação de novos bairros e constitui instrumento de mobilidade social. Sob a forma de cantarias, a rocha torna-se símbolo de elegância, do qual o maior representante é o gnaisse facoidal que, com sua beleza rústica realçada pelos entalhes

Figura 30. Localização de edifícios e logradouros mencionados no texto: (1) Largo de São Francisco; (2) Pedreira do Morro da Conceição; (3) antigo Beco das Pedreiras; (4) Igreja da Candelária; (5) Casa França-Brasil; (6) Centro Cultural dos Correios; (7) Centro Cultural Banco do Brasil; (9) Igreja Nossa Senhora da Lapa dos Pescadores; (10) Sebo da Rua do Rosário, 38; (11) Chafariz do Paço; (12) Igreja da Sé e o Convento do Carmo e (13) Igreja Santa Cruz dos Militares. Base cartográfica: Prefeitura municipal do Rio de Janeiro (1997)

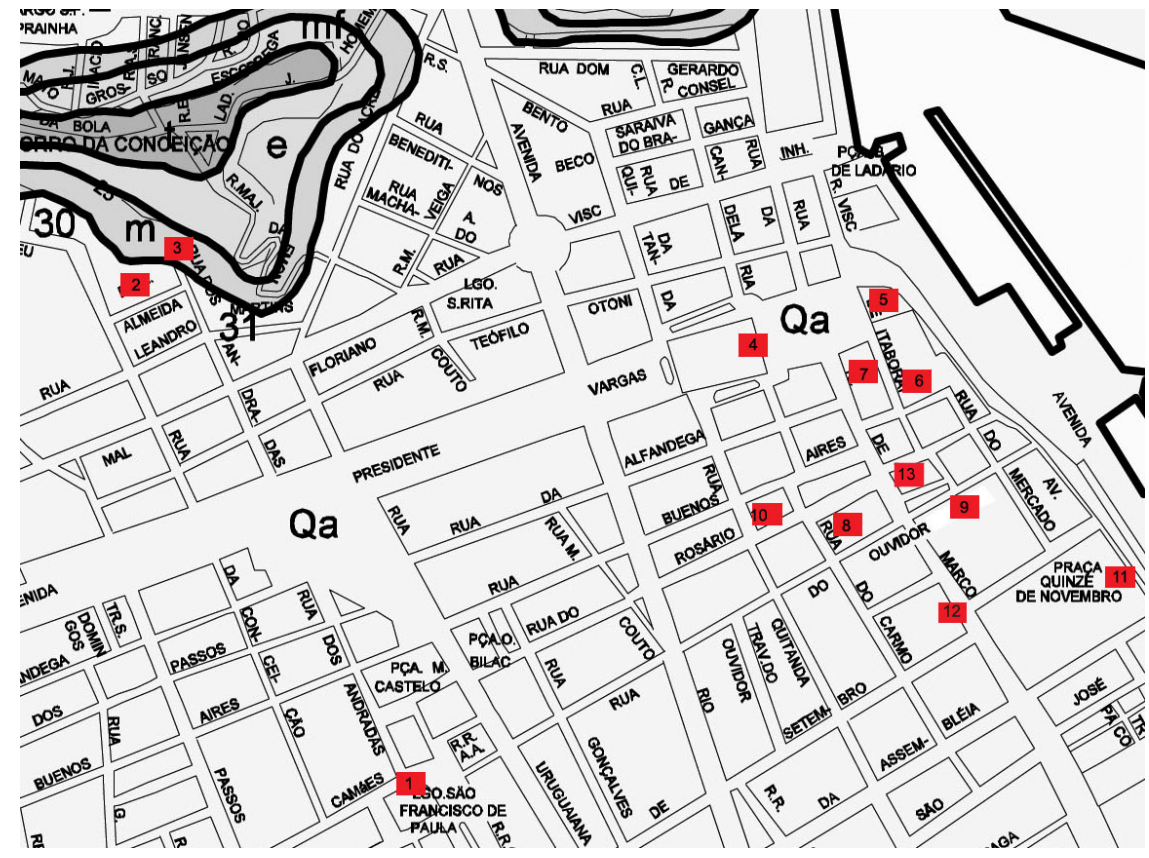




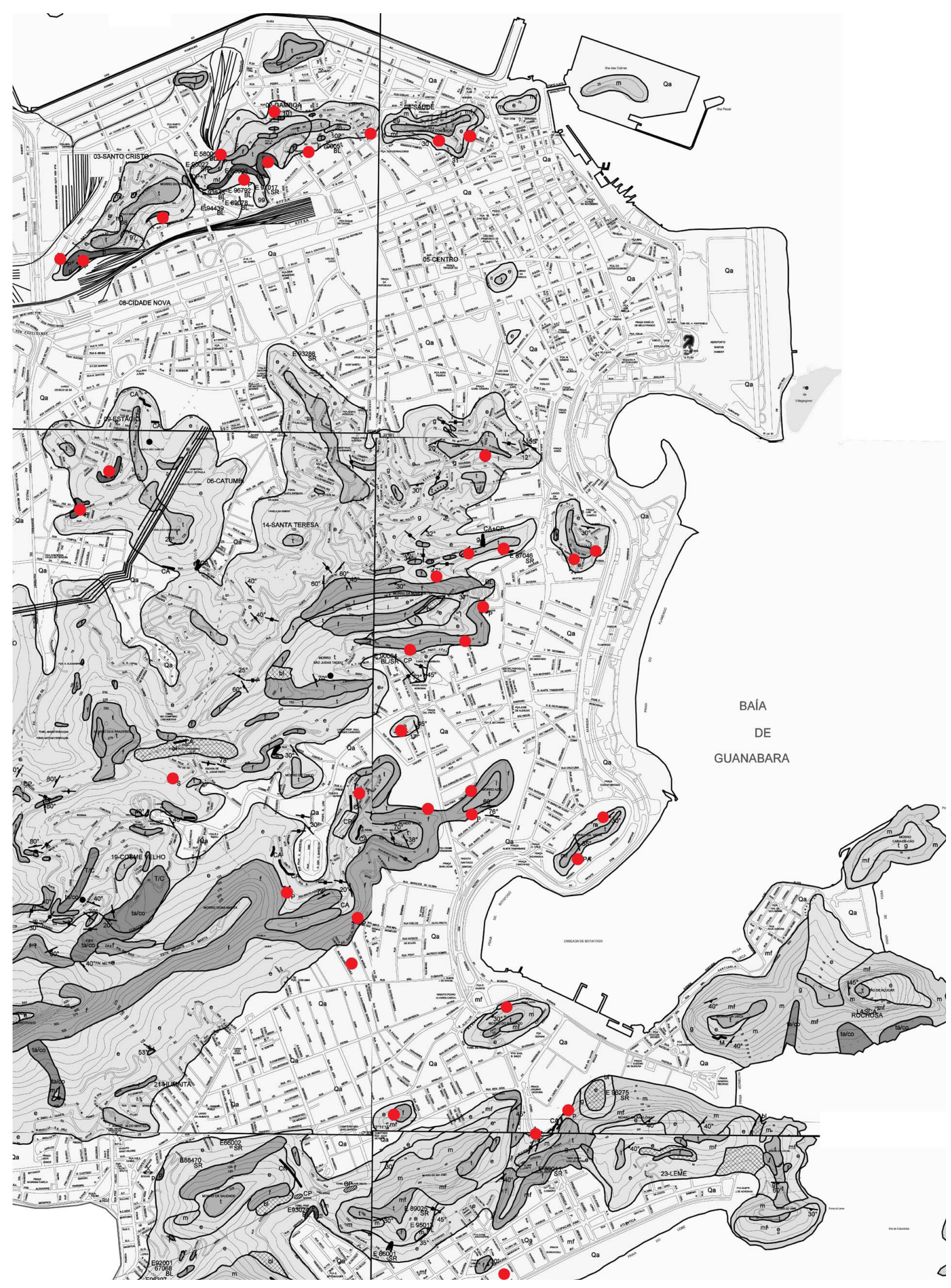

Figura 31. Localização de frentes desativadas de pedreiras na região entre o Centro Histórico e a Zona Sul da Cidade do Rio de Janeiro. Base cartográfica: Prefeitura Municipal do Rio de janeiro (1997) 
à mão torna-se um dos elementos representativo da identidade da cidade do Rio de Janeiro e arredores.

As antigas pedreiras se revelam, portanto, como instrumentos que influenciaram no desenvolvimento da cidade e em suas relações sócio-econômicas e, neste contexto, devem ser consideradas não apenas como vestígios de um processo extrativista, mas como um patrimônio natural que, trabalhado pelas mãos dos homens, transforma-se em patrimônio histórico e cultural, sob a forma de edifícios, adornos e monumentos que podem ser utilizados como recursos didáticos no ensino de geologia para públicos de diversas idades e perfis.

O conhecimento das relações históricas permite que seja estabelecida uma conexão entre a geologia e o cotidiano. Visitas às pedreiras e prédios históricos, ao longo de um roteiro como o aqui sugerido, permitem uma avaliação do processo de extração sob uma perspectiva histórica, gerando um vínculo emocional e aumentando o interesse, por parte dos participantes, em conhecer as características das rochas no que concerne ao seu aspecto, suas propriedades físicas e sua composição. Por meio das atividades alternadas nas pedreiras e no centro histórico, é possível comparar as características da rocha em seu estado natural e depois de trabalhada em seus vários aspectos, por diversas gerações, ao longo de séculos de nossa história. Desta forma, as pedreiras, cujas origens remontam ao nascimento do país, são partes integrantes da construção de nossa identidade e devem ser encaradas como patrimônio geológico e histórico. Muitas delas estão, hoje, situadas em locais apropriados para a instalação de museus com forte

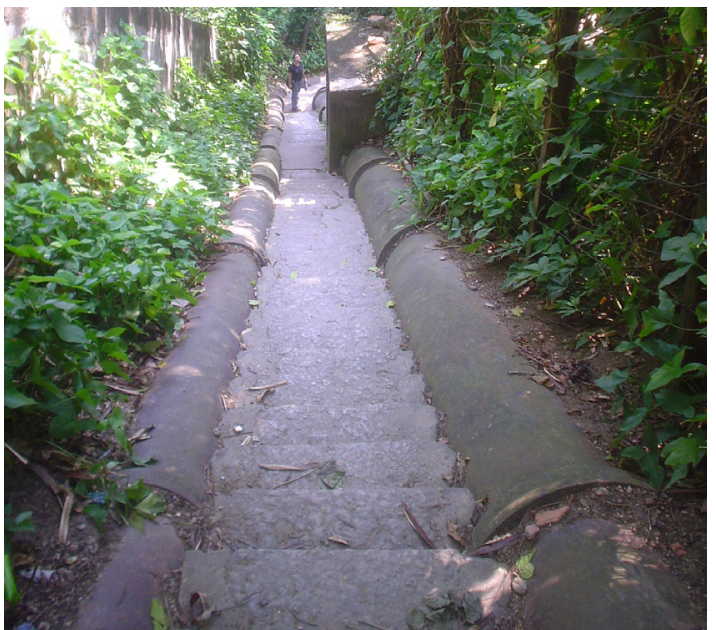

Figura 32. Escadaria estruturada em gnaisse facoidal para acesso ao Reservatório do Morro da Viúva. Acesso pela Travessa Acaraí

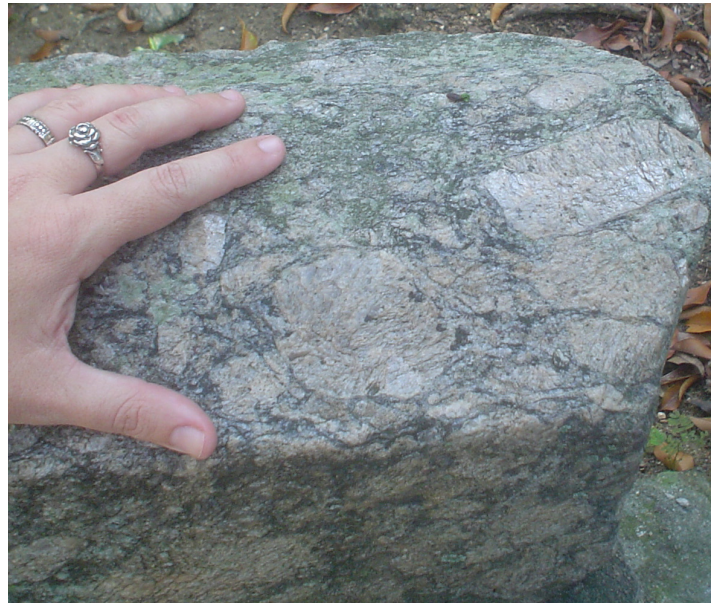

Figura 33. Contrate textural entre megacristais tabulares e ocelares, refletindo diferentes graus de deformação em amostra de gnaisse facoidal do Morro da Viúva

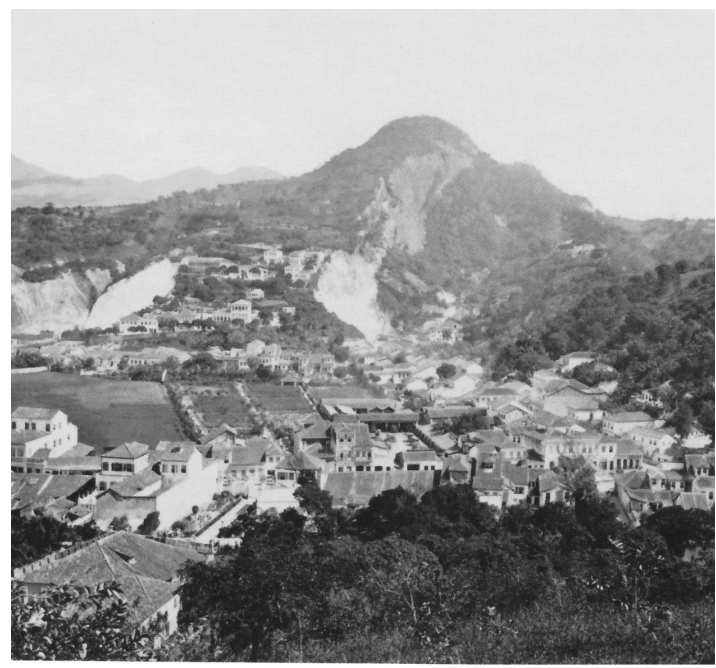

(A)

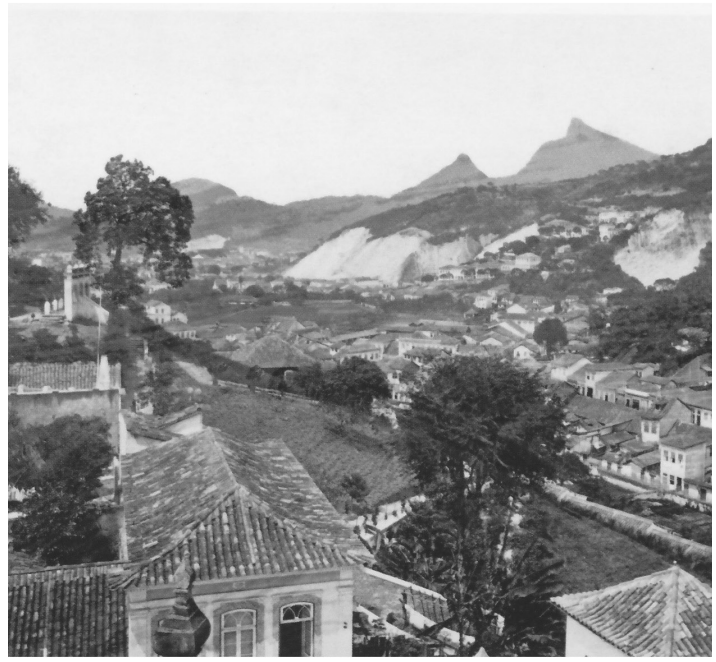

Figura 34. Rua das Laranjeiras tendo, aos fundos, as pedreiras do Morro da Nova Cintra, região da antiga pedreira da Candelária. Fotos de 1889. Extraída de Lago \& Lago (2008) 


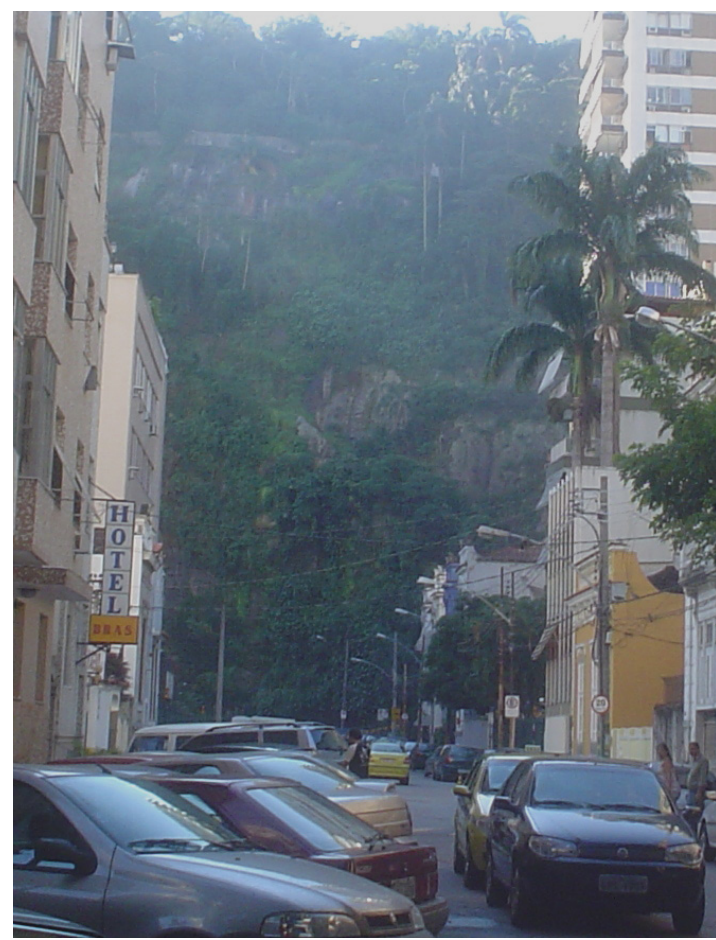

Figrua 35. Frente de pedreira do Morro da Nova Cintra aos fundos da Rua Marquesa de Santos, próximo ao Largo do Machado, região da antiga Pedreira da Candelária

potencial turístico à semelhança, por exemplo, do Threlkeld Quarry Mining Museum, situado no Reino Unido, e de vários museus norte-americanos (Tenino Depot Museum, Griffith Quarry Museum e o Granite Quarrying History Museum, entre outros).

O papel das atividades das pedreiras do ponto de vista histórico também traz elementos que con-

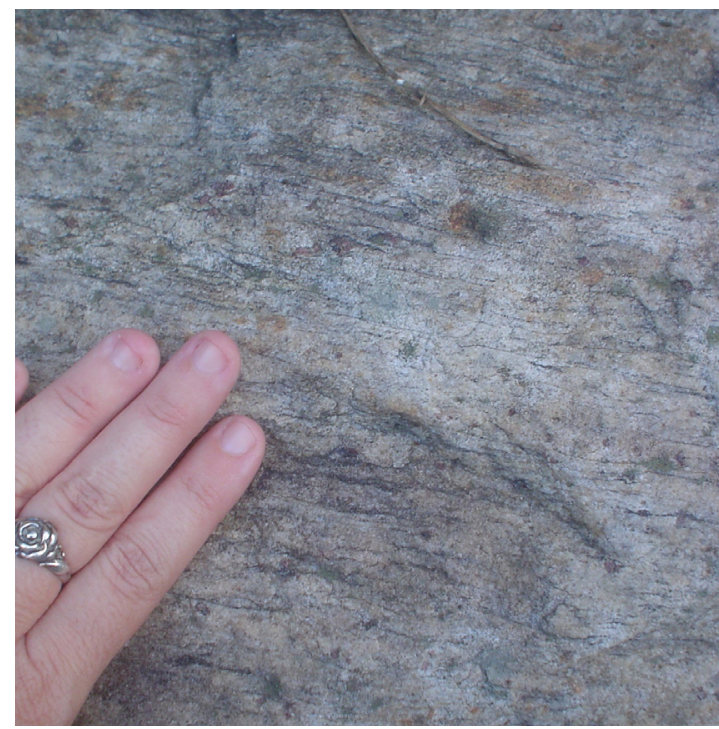

Figura 36. Leptinito aflorante em frente da Rua Marquesa de Santos, região da antiga Pedreira da Candelária tribuem para reflexões sobre questões ligadas ao meio-ambiente. É senso comum que a explotação de rochas resulta em danos ao meio-ambiente, dentre os quais a retirada da vegetação local, o uso de explosivos e a geração de poeira, causando distúrbios para a população local. Nos relatos históricos de viajantes que passaram pelo Rio de Janeiro, há várias menções sobre esta questão, principalmente no que se refere à degradação visual e ao uso de explosivos. $\mathrm{O}$ impacto visual à época das extrações das pedreiras pode ser avaliado em várias das imagens apresentadas neste trabalho. Nas imagens da Figura 15, entretanto, nota-se que tal impacto perde sua dimensão diante da ocultação das pedreiras pelos edifícios modernos, que

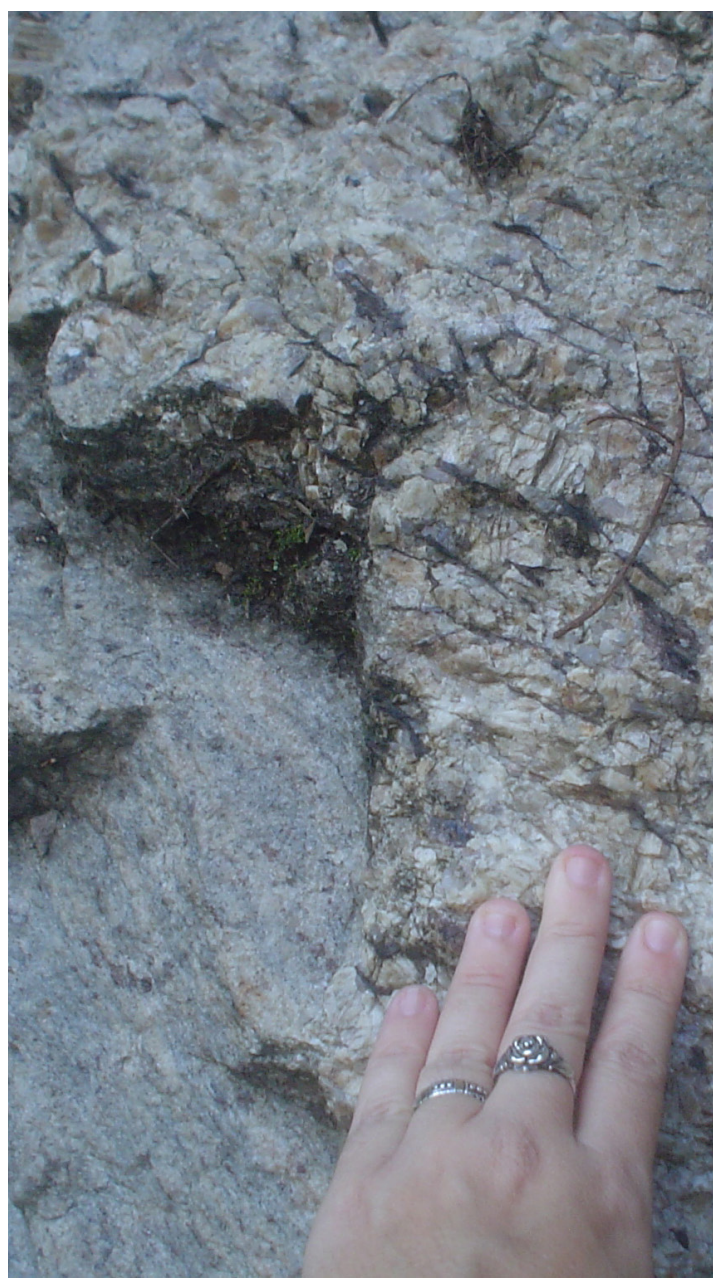

Figura 37. Detalhe de pegmatito em leptinito em antiga frentes de pedreira localizada na rua Marquesa de Santos, região da antiga Pedreira da Candelária. Estas mesmas feições podem ser observadas nas contarias da Igreja da Candelária (ver Figura 22) 
escondem não só as antigas frentes, mas também a vegetação e os morros intocados. Os gigantescos cortes de rocha que feriam os olhos dos viajantes até o século XIX, adquiriram proporções insignificantes diante das construções que hoje dominam a paisagem. A poluição sonora agora se traduz não pelas explosões, mas pelo som produzido por automóveis que também exalam gases poluentes. Este fato demonstra a existência de diferentes níveis de tolerância para elementos que têm em comum a transformação da paisagem natural.

\section{Agradecimentos}

Os autores agradecem a colaboração de Kátia Andreolla e Camila Mansur no desenvolvimento do trabalho.

\section{Referências}

Abreu S.F. 1957. O Distrito Federal e seus Recursos Naturais. IBGE. Série A livros No14. 318 p.

Abreu M.A. 2010. Evolução Urbana do Rio de Janeiro. $4^{\mathrm{a}}$. ed. Instituto Pereira Passos. Prefeitura da Cidade do Rio de Janeiro.

Aguiar A.P. 2002. Análise histórica da evolução conceitual da Geologia na Cidade do Rio de Janeiro nos últimos 150 anos. DEGEOC/UFRRJ. 68p. (Monogr. de Graduação).

Araújo C.E.M. 2009. Cárceres Imperiais: A casa de correção do Rio de Janeiro, seus detentos e o sistema prisional no Império, 1830-1861. Campinas: Univ. Est. Campinas. 336p. (Tese Dout. IFCH Progr. Pós-Grad. História).

Azevedo M. 1877. Rio de janeiro, sua história, movimentos, homens notáveis, usos e costumes. Vol. I B.L. Garnier Ed. 448 p.

Coroacy V. 1888. Memórias da cidade do Rio de Janeiro. São Paulo: EDUSP. 401 p.

Debret J.B.1835. Viagem pitoresca ao Brasil. Tomo III. São Paulo: Ed. Martins/Edusp. 272p. (Ed. de 1989).

Dennis P. 1911. Londres: T. Fisher Unwin Ed. 388 p.

Ermakoff G. 2009. Augusto Malta e o Rio de Janeiro 1903-1936. G. Ermakoff Casa Editorial. 284p.

Ermakoff G. 2006. Rio de Janeiro 1840-1900 - Uma crônica fotográfica. G. Ermakoff Casa Editorial. $258 \mathrm{p}$.
Fernandes M. 2008. A taipa no mundo. Seminário de Construção e Recuperação de Edifícios em Taipa. Apresentação oral na Câmara Municipal de Almodôvar.

França J.M.C. 2000. Visões do Rio de Janeiro Colonial. Antologia de textos. José Olympio Ed. 261 p.

Gerson B. 2000. Histórias das Ruas do Rio. Lacerda Ed. 513p.

Heilbron M., Valeriano C.M., Almeida J.C.H., Valladares C.S., Tupinambá M. 1994. Segmento Central da Faixa Ribeira, exemplo de colisão continental oblíqua no evento termo-tectônico Brasiliano. In: Congr. Bras. De Geol., 38, Balneário de Camboriú, 1994. Bol. Res. Expandidos... SBG, vol 1: 263-265.

Heilbron M., Valeriano C.M., Valladares C.S., Machado N. 1995. A orogênese Brasiliana no segmento central da Faixa Ribeira, Brasil. Rev. Bras. Geoc. 25(4): 245-266.

Helmbold R. ; Valença J.G., Leonardos Jr., O.H. 1965. Mapa geológico do Estado da Guanabara, esc. 1: 50000. 3 Folhas. MME/DNPM.

IMS. Instituto Moreira Sales. 2005. O Brasil de Mark Ferrez. 214 p.

Instituto Estadual do patrimônio Cultural. Inepac. 1998. Guia de Bens Tombados: Morro da Viúva. Proc.: E-18/001.542/98. URL: http://www.inepacrj.gov. $\mathrm{br} /$ modules.php? name $=$ Guia\&file $=$ consulta detalhe_bem\&idbem $=316$ [www.inepac.rj.gov. br] Acesso: 06/09/2010.

Kidder D.P., Fletcher J.C. 1857. Brazil an the Brazilians. Phillips Sampson \& Com. Ed. 630 p.

Lago P., Lago B.C. 2008. Coleção Princesa Isabel. Fotografias do Século XIX. Ed. Capivara. 431 p.

Leonardos Jr. O.H. 1973.The origin and alteration of granite rocks in Brazil: a study of metamorphism, anatexis, weathering, and fertility within granitic terrains in eastern Brazil. Univ. Manchester, England, 183p. (Ph.D. Thesis).

Lima O. 1908. Dom João VI no Brazil. 1808-1821. Typ. Do Jornal do Commercio Ed. Vol I. 604 p.

Mello Morais A. J. 1997. Chronica Geral do Brasil 1500-1700. Tomo I. LGarnier Ed. 622 p.

Pires F.R.M, Bauer E.H, Crescencio Jr. F., Gonzaga G.G., Torrs M.G. 1989. Lito-estratigrafia dos gnaisses da Floresta da Tijuca, Rio de Janeiro, RJ. $1^{\circ}$ Simp. Geol. Sudeste, Rio de Janeiro, Bol. Res. Expand. p: 153-154.

Pires F.R.M., Heilbron M., Alburqueque R., Bessa M.P. 1983. Characterization of a poliphase 
deformation in gneisses and migmatites of Rio de Janeiro. An. Acad. bras. Ciênc., 5(4):453-454.

Pires F.R.M., Valença J.G., Ribeiro A. 1982. Multistage generation of granite in Rio de Janeiro, Brazil. An. Acad. bras. Ci., 54(3):563-574.

Porto Jr R, Valente S.C. 1988. As rochas granitóides do norte da Serra da Pedra Branca e suas relaçöes com as encaixantes gnaissicas na regiäo de Bangu, Rio de Janeiro, RJ. In: Congr. Bras. Geol., 35, Belém, 1988. Anais... Belem, SBG. v. 3, p. 1066-1079.

Porto Jr R. 1994. Petrologia das Rochas das Serras da Pedra Branca e Misericórdia, Rio de Janeiro, RJ. IG/UFRJ. 224 p. (Dissert. Mestr.)

Porto Jr R. 1996. Histórico Secular da Geologia da Cidade do Rio de Janeiro.. In: XXXIX Cong. Bras. Geol. Anais. Vol 4: 124-128., 1996, Salvador. Anais do XXXIX Cong. Bras. Geol., 1996. v. 2. p. 186-189.

Porto Jr R. 2004. Petrogênese das Rochas do Maciço da Pedra Branca, Rio de Janeiro, RJ. . IG/UFRJ. 231p. (Tese Dout.)

Porto Jr R., Aguiar. 2000. Geology in the Rio de Janeiro County: the first years. XXXI Int. Geological Congress. Rio de Janeiro. CD-ROM.

Prefeitura Municipal do Rio de Janeiro. 1997. Mapeamento Geológico-Geotécnico da Cidade do Rio de Janeiro. Secretaria de Obras e Serviços Públicos. Carta 1:10.000.
Rugendas J.M. 1889. Viagem pitoresca através do Brasil. São Paulo: Ed. Martins/Edusp. 166p. (Ed. de 1989). Schwarez L.M. 1999. As Barbas do Imperador. D Pedro II, um monarca nos trópicos. Cia. Das letras. $623 \mathrm{p}$.

Sendyk F. coord. 2000. Do cosmógrafo ao satélite. Prefeitura da Cidade do Rio de janeiro. 135p.

Souza J.V. 1898. A igreja da Candelária desde sua fundação. Fac-símile de Igreja da Candelária desde a sua fundação. Ed. Debret. Typ. Leuzinger \& Filhos. Fac-símile de 1998. 134 p.

Staunton G.L. An authentic account of an embassy from the King of Great Britain to the Emperro of China.

Tupinambá M. 1999. Evolução Tectônica da Faixa Ribeira na Região Serrana do Estado do Rio de Janeiro. . IG/USP. 221p. (Tese Dout.)

Tupinambá M.; Teixeira W.; Heilbron M., Basei M. 1998. U/Pb zircon age and litogeochemistry of the Rio Negro Complex tonalitic gneiss: evidence of a $630 \mathrm{Ma}$ magmatic arc at the Costeiro Domain of the Ribeira Belt. XXXIX Cong. Bras. Geol. Anais. São Paulo, SBGeo, p:51.

Von Spix J.B., Von Martius. C.F.P 1824 Travels in Brazil in the years 1817-1820. Londres. 330p.

Zylberg S. 1992. Morro da Providência: memória da favela. Prefeitura Municipal do Rio de Janeiro. Secretaria Municipal de Cultura, Turismo e Esporte. 122 p. 